\title{
Ground-Water Quality Assessment of the Georgia-Florida Coastal Plain Study Unit-- Analysis of Available Information on Nutrients, 1972-92
}

By Marian P. Berndt

\section{U.S. GEOLOGICAL SURVEY}

Water-Resources Investigations Report 95-4039

NATIONAL WATER-QUALITY ASSESSMENT PROGRAM--

GEORGIA-FLORIDA COASTAL PLAIN STUDY UNIT

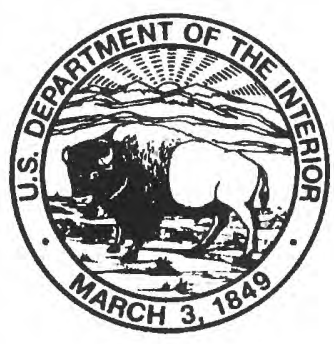




\title{
U.S. DEPARTMENT OF THE INTERIOR BRUCE BABBITT, Secretary
}

\author{
U.S. GEOLOGICAL SURVEY \\ Gordon P. Eaton, Director
}

Any use of trade, product, or firm names in this publication is for descriptive purposes only and does not imply endorsement by the U.S. Geological Survey.

For additional information write to:

District Chief

U.S. Geological Survey

Suite 3015

227 North Bronough Street

Tallahassee, Florida 32301
Copies of this report can be purchased from:

U.S. Geological Survey Earth Science Information Center Open-File Reports Section

P.O. Box 25286, MS 517

Denver, CO 80225-0425 


\section{FOREWORD}

The mission of the U.S. Geological Survey (USGS) is to assess the quantity and quality of the earth resources of the Nation and to provide information that will assist resource managers and policymakers at Federal, State, and local levels in making sound decisions. Assessment of water-quality conditions and trends is an important part of this overall mission.

One of the greatest challenges faced by waterresources scientists is acquiring reliable information that will guide the use and protection of the Nation's water resources. That challenge is being addressed by Federal, State, interstate, and local water-resource agencies and by many academic institutions. These organizations are collecting water-quality data for a host of purposes that include: compliance with permits and water-supply standards; development of remediation plans for a specific contamination problem; operational decisions on industrial, wastewater, or watersupply facilities; and research on factors that affect water quality. An additional need for water-quality information is to provide a basis on which regional and national-level policy decisions can be based. Wise decisions must be based on sound information. As a society we need to know whether certain types of water-quality problems are isolated or ubiquitous, whether there are significant differences in conditions among regions, whether the conditions are changing over time, and why these conditions change from place to place and over time. The information can be used to help determine the efficacy of existing waterquality policies and to help analysts determine the need for and likely consequences of new policies.

To address these needs, the Congress appropriated funds in 1986 for the USGS to begin a pilot program in seven project areas to develop and refine the National Water-Quality Assessment (NAWQA) Program. In 1991, the USGS began full implementation of the program. The NAWQA Program builds upon an existing base of water-quality studies of the USGS, as well as those of other Federal, State, and local agencies. The objectives of the NAWQA Program are to:

-Describe current water-quality conditions for a large part of the Nation's freshwater streams, rivers, and aquifers.

-Describe how water quality is changing over time.
-Improve understanding of the primary natural and human factors that affect water-quality conditions.

This information will help support the development and evaluation of management, regulatory, and monitoring decisions by other Federal, State, and local agencies to protect, use, and enhance water resources.

The goals of the NAWQA Program are being achieved through ongoing and proposed investigations of 60 of the Nation's most important river basins and aquifer systems, which are referred to as study units. These study units are distributed throughout the Nation and cover a diversity of hydrogeologic settings. More than two-thirds of the Nation's freshwater use occurs within the 60 study units and more than two-thirds of the people served by public water-supply systems live within their boundaries.

National synthesis of data analysis, based on aggregation of comparable information obtained from the study units, is a major component of the program. This effort focuses on selected water-quality topics using nationally consistent information. Comparative studies will explain differences and similarities in observed water-quality conditions among study areas and will identify changes and trends and their causes. The first topics addressed by the national synthesis are pesticides, nutrients, volatile organic compounds, and aquatic biology. Discussions on these and other waterquality topics will be published in periodic summaries of the quality of the Nation's ground and surface water as the information becomes available.

This report is an element of the comprehensive body of information developed as part of the NAWQA Program. The program depends heavily on the advice, cooperation, and information from many Federal, State, interstate, Tribal, and local agencies and the public. The assistance and suggestions of all are greatly appreciated. 



\section{CONTENTS}

Abstract

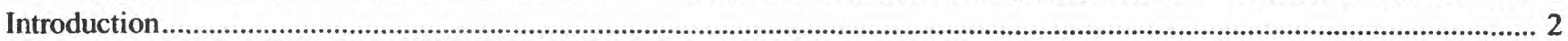

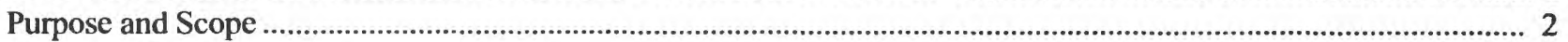

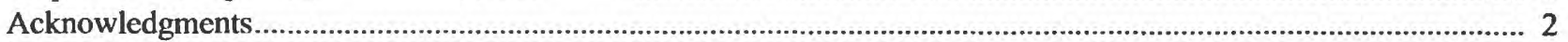

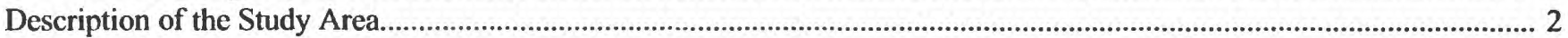

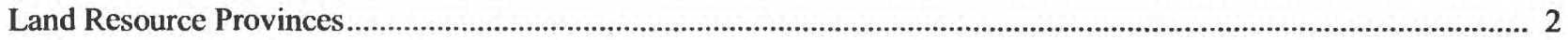

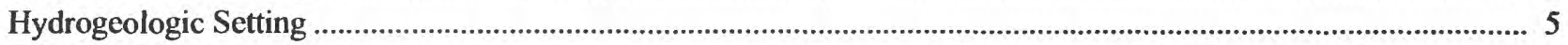

Climate

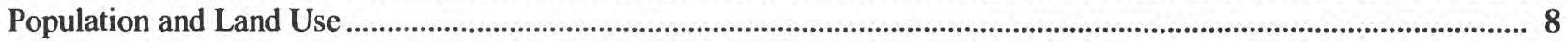

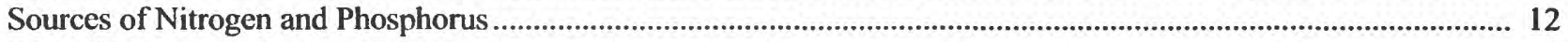

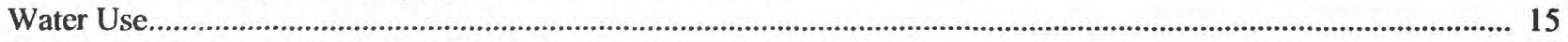

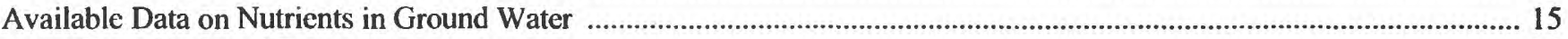

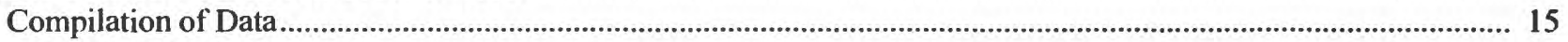

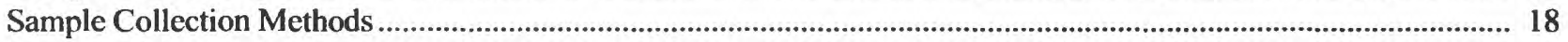

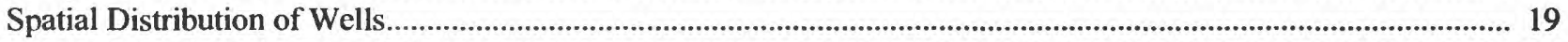

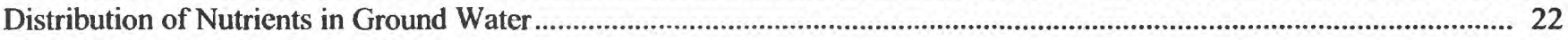

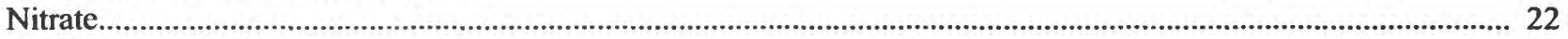

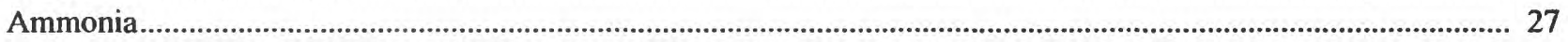

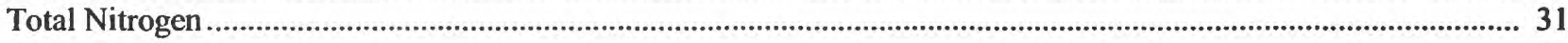

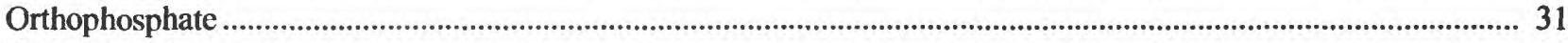

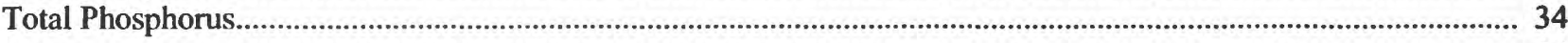

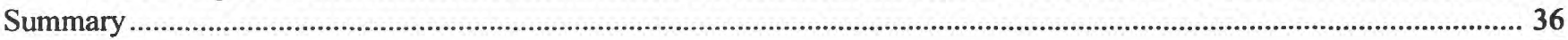

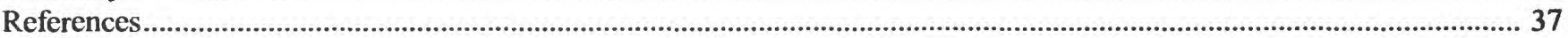

\section{FIGURES}

1-9. Maps showing:

1. Location of Georgia-Florida Coastal Plain study area ............................................................................................... 3

2. Land resource provinces in the Georgia-Florida Coastal Plain................................................................................ 4

3. Areas of confined, semiconfined, and unconfined conditions for the Floridan aquifer system in the Georgia-Florida Coastal Plain

4. Urban land-use areas in the Georgia-Florida Coastal Plain. ..............................................................................

5. Forest land-use areas in the Georgia-Florida Coastal Plain. ............................................................................. 10

6. Agricultural land-use areas in the Georgia-Florida Coastal Plain.................................................................... 11

7. Estimated nitrogen inputs from manure, fertilizers, and septic tanks by county in the Georgia-Florida Coastal Plain, 1990.

8. Estimated phosphorus inputs from manure, fertilizers, and septic tanks by county

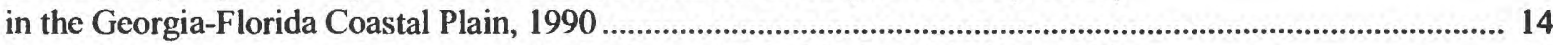

9. Ground-water withdrawals by county in the Georgia-Florida Coastal Plain, 1990 .......................................... 16

10-11. Bar charts showing:

10. Ground-water withdrawals by State and by category in the Georgia-Florida Coastal Plain, 1990.................... 17

11. Number of ground-water samples collected per year, 1972-92, from three data sources in the Georgia-Florida Coastal Plain.

12-13. Maps showing:

12. Locations of wells in the U.S. Geological Survey data in the Georgia-Florida Coastal Plain.

13. Map showing locations of wells in the Florida Department of Environmental Protection and Georgia Geologic Survey data in the Georgia-Florida Coastal Plain.

14. Boxplot showing depth distribution of wells from three data sources. 
15-16. Bar charts showing:

15. Distribution of samples in various land-use areas from three data sources

16. Distribution of nitrate concentrations in ground-water samples from three data sources.

17-21. Boxplots showing:

17. Nitrate concentrations in water from the Upper Floridan aquifer in confined, semiconfined, and unconfined areas for agricultural, forest, and urban areas of the Georgia-Florida Coastal Plain (U.S. Geological Survey data)...

18. Nitrate concentrations in water from the surficial aquifer system in land resource provinces for agricultural, forest, and urban areas of the Georgia-Florida Coastal Plain (U.S. Geological Survey data).

19. Nitrate concentrations in water from the Upper Floridan aquifer in confined, semiconfined and unconfined areas for agricultural, forest, and urban areas of the Georgia-Florida Coastal Plain (Florida Department of Environmental Protection data).

20. Nitrate concentrations in water from the surficial aquifer system in land resource provinces for agricultural, forest, and urban areas of the Georgia-Florida Coastal Plain (Florida Department of Environmental Protection data).

21. Nitrate concentrations in ground water in land resource provinces for agricultural, forest, and urban areas of the Georgia-Florida Coastal Plain (Georgia Geologic Survey data).

22-24. Graphs showing:

22. Nitrate concentrations for the time period, 1972-91, in ground water from the unconfined Upper Floridan aquifer in agricultural areas in central Florida in the Georgia-Florida Coastal Plain (U.S. Geological Survey)......

23. Nitrate concentrations for the time period, 1972-91, in ground water from the unconfined and semiconfined Upper Floridan aquifer in forest areas in central Florida in the Georgia-Florida Coastal Plain (U.S. Geological Survey).

24. Nitrate concentrations for the time period, 1972-89, in ground water from the unconfined Upper Floridan aquifer in urban areas in central Florida in the Georgia-Florida Coastal Plain (U.S. Geological Survey)

25-33. Boxplots showing:

25. Ammonia concentrations in water from the Upper Floridan aquifer in confined, semiconfined, and unconfined areas for agricultural, forest, and urban areas of the Georgia-Florida Coastal Plain (U.S. Geological Survey data)....

26. Ammonia concentrations in water from the surficial aquifer system in land resource provinces for agricultural, forest, and urban areas of the Georgia-Florida Coastal Plain (U.S. Geological Survey data).

27. Total nitrogen concentrations in water from the Upper Floridan aquifer in confined, semiconfined, and unconfined areas for agricultural, forest, and urban areas of the Georgia-Florida Coastal Plain (U.S. Geological Survey data)

28. Total nitrogen concentrations in water from the surficial aquifer system in land resource provinces for agricultural, forest, and urban areas of the Georgia-Florida Coastal Plain (U.S. Geological Survey data).

29. Orthophosphate concentrations in water from the Upper Floridan aquifer in confined, semiconfined, and unconfined areas for agricultural, forest, and urban areas of the Georgia-Florida Coastal Plain (U.S. Geological Survey data)

30. Orthophosphate concentrations in water from the surficial aquifer system in land resource provinces for agricultural, forest, and urban areas of the Georgia-Florida Coastal Plain (U.S. Geological Survey data) ......... 33

31. Orthophosphate concentrations in water from the Upper Floridan aquifer in confined, semiconfined, and unconfined areas and from the surficial aquifer system in the Georgia-Florida Coastal Plain (Florida Department of Environmental Protection data).

32. Total phosphorous concentrations in water from the Upper Floridan aquifer in confined, semiconfined, and unconfined areas for agricultural, forest, and urban areas of the Georgia-Florida Coastal Plain (U.S. Geological Survey data)

33. Total phosphorus concentrations in water from the surficial aquifer system in land resource provinces for agricultural, forest, and urban areas of the Georgia-Florida Coastal Plain (U.S. Geological Survey data). 


\section{TABLES}

1. Description of major aquifers in the Georgia-Florida Coastal Plain......................................................................

2. Long-term average temperature and rainfall in selected cities in the Georgia-Florida Coastal Plain, 1961-90 ............. 8

3. Land use percentages in the Georgia-Florida Coastal Plain ............................................................................. 8

4. Description of sources of selected nitrogen and phosphorus data for ground water in the Georgia-Florida Coastal Plain.

5. Numbers of ground-water samples with data for selected nitrogen and phosphorus species from three data sources in the Georgia-Florida Coastal Plain.

6. Median concentrations of nitrogen and phosphorus species from three data sources in the Georgia-Florida Coastal

Plain.....

\section{CONVERSION FACTORS, ACRONYMS, AND ADDITIONAL ABBREVIATIONS}

\begin{tabular}{rll}
\hline \multicolumn{1}{r}{ Multiply } & By & To obtain \\
\hline inch & 2.54 & centimeter \\
foot & 0.3048 & meter \\
acre & 4,047 & square meter \\
mile & 1.609 & kilometer \\
square ${\mathrm{mile}\left(\mathrm{mi}^{2}\right)}^{2}$ & 2.590 & square kilometer \\
million gallons per day $(\mathrm{Mgal} / \mathrm{d})$ & 3,785 & cubic meters per day \\
tons per square mile (tons/mi & & \\
\hline
\end{tabular}

Temperature in degrees Fahrenheit $\left({ }^{\circ} \mathrm{F}\right)$ can be converted to degrees Celsius $\left({ }^{\circ} \mathrm{C}\right)$ as follows:

$$
{ }^{\circ} \mathrm{C}=(0.556) \cdot\left({ }^{\circ} \mathrm{F}-32\right)
$$

\section{Acronyms and abbreviations used in report}

FDEP = Florida Department of Environmental Protection

GGS = Georgia Geologic Survey

NAWQA $=$ National Water Quality Assessment Program

USGS = U.S. Geological Survey

$\mathrm{mg} / \mathrm{L} \quad=$ milligrams per liter 



\section{Ground-Water Quality Assessment of the Georgia-Florida Coastal Plain Study Unit-- Analysis of Available Information on Nutrients, 1972-92}

By Marian P. Berndt

\section{ABSTRACT}

The U.S. Geological Survey is conducting an assessment of water quality in the GeorgiaFlorida Coastal Plain study unit as part of the National Water-Quality Assessment Program. An initial activity of the program is to compile and analyze existing water-quality data for nutrients in each study unit. Ground-water quality data were compiled from three data sources, the U.S. Geological Survey, Florida Department of Environmental Protection, and Georgia Geologic Survey. A total of 2,246 samples of ground water nutrient data for nitrogen and phosphorus species were compiled from these three data sources. Estimates of 1990 nitrogen and phosphorus inputs by county in the study area were calculated from livestock manure, fertilizers, septic tanks, and rainfall.

Data for nitrate nitrogen concentrations in ground water were available from the greatest number of wells; samples from 1,233 wells were available in the U.S. Geological Survey, 820 wells from the Florida Department of Environmental Protection, and 680 wells from the Georgia Geologic Survey. The maximum contaminant level for nitrate nitrogen in drinking water of 10 milligrams per liter was exceeded in a higher percentage of samples from the U.S. Geological Survey, mostly because this data contained numerous samples near known contamination areas. The maximum contaminant level for nitrate nitrogen was exceeded in 3 percent of samples from Upper Floridan aquifer and 12 percent of samples from surficial aquifer system in U.S. Geological Survey data and less than 1 percent and 2 percent of samples from the Upper Floridan aquifer and surficial aquifer system, respectively, in Florida Department of Environmental Protection data. In Georgia Geologic Survey data, 1 percent of samples had concentrations of nitrate nitrogen exceeding 10 milligrams per liter.

Nutrient concentration data were grouped into categories based on land use, hydrogeology (aquifer and confinement of the Upper Floridan aquifer), and land resource provinces (Central Florida Ridge, Coastal Flatwoods and Southern Coastal Plain) for the surficial aquifer system. The highest median nitrate nitrogen concentrations in the U.S. Geological Survey data were 0.4 milligrams per liter in ground-water samples from the unconfined Upper Floridan aquifer in agricultural areas and 9.0 milligrams per liter in samples from the surficial aquifer system in agricultural areas in the Central Florida Ridge. In Florida Department of Environmental Protection data, the highest median nitrate nitrogen concentrations were much lower and did not exceed 0.2 milligrams per liter in either the Upper Floridan aquifer or the surficial aquifer system. In Georgia Geologic Survey data the highest median nitrate nitrogen concentration was 1.4 milligrams per liter in agricultural areas in the Coastal Flatwoods. Highest median concentrations of total nitrogen of 10 milligrams per liter (includes nitrate, ammonia, and organic nitrogen) were in U.S. Geological Survey data in the surficial aquifer system in agricultural areas in the Central Florida Ridge. Median concentrations of ammonia nitrogen, orthophosphate phosphorus, and total phosphorus did not exceed 0.5 milligrams per liter in all categories from the Upper Floridan aquifer or the surficial aquifer system. 


\section{INTRODUCTION}

Across the Nation, 60 study units have been established as part of the National Water-Quality Assessment (NAWQA), consisting of hydrologic systems that include parts of most major river basins and aquifer systems. These study units cover areas of 1,200 to nearly 62,000 square miles $\left(\mathrm{mi}^{2}\right)$ and incorporate about 60 to 70 percent of the Nation's water use. The Georgia-Florida Coastal Plain study unit was among 20 NAWQA study units selected when the USGS began full implementation of the program in 1991.

One of the initial activities undertaken as part of the NAWQA program was to compile and analyze available water-quality data for nutrients (nitrogen and phosphorus species) in each study area. This report provides an initial assessment of nutrient data for ground water in the Georgia-Florida Coastal Plain study unit available as of 1993 in USGS, Florida Department of Environmental Protection (FDEP) Ground Water-Quality Monitoring Program, and the Georgia Geologic Survey (GGS) water-quality data bases. Areas within the study area where water-quality problems occur and where nutrient water-quality data are lacking are also discussed.

\section{Purpose and Scope}

The purposes of this report are to describe the spatial and temporal availability of nutrients data for ground water within the Georgia-Florida Coastal Plain study area, and to provide an assessment of nitrogen and phosphorus concentrations in ground water. The report describes the major data sources, identifies differences in the geographic regions and time periods covered by the data sources, and describes variations in nitrogen and phosphorus concentrations by hydrogeology, general soils and land use. A summary of the major sources of data and the general characteristics of the data for regional assessment of nitrogen and phosphorus concentrations in ground water are presented. Summary statistics and graphical summaries of nitrogen and phosphorus concentration in ground water are presented for each data source. Nitrate as nitrogen concentrations are compared to the drinking water quality standard. Nitrogen and phosphorus inputs from fertilizers, manure, septic tanks, and precipitation are also discussed.

The scope of this report includes a description and analysis of available and accessible nitrogen and phosphorus data (nitrate, ammonia, total nitrogen, orthophosphate, and total phosphorus) for ground- water samples collected from 1972 through 1992 in the study area from several data sources. The data discussed in this report were accessible from computer files as of early 1993. Some accessible data was not used because adequate information was available for selected geographic regions. Nitrogen and phosphorus inputs were estimated for 1990 .

\section{Acknowledgments}

The author thanks the personnel from agencies who contributed data used in this report: Paul Hansard of the Florida Department of Environmental Protection and Sandra Jo Robertson of the Georgia Geologic Survey. The author also thanks the members of the Georgia-Florida Coastal Plain study unit liaison committee for their comments and support during this effort.

\section{DESCRIPTION OF STUDY AREA}

The Georgia-Florida Coastal Plain study area, encompassing nearly $62,000 \mathrm{mi}^{2}$, is located on the southeastern coast of the United States (fig. 1). The study area includes all or parts of 135 counties in the States of Georgia and Florida (fig.1). The study area extends from Atlanta in north-central Georgia, to central Florida and includes the cities of Jacksonville, Orlando, St.Petersburg, and Tampa in Florida.

\section{Land Resource Provinces}

Land resource provinces have been designated based on generalized soil classifications mapped by U.S. Department of Agriculture for the states of Florida and Georgia in cooperation with State governments (Perkins and Shaffer, 1977; Caldwell and Johnson, 1982). The occurrence of nutrients in ground water in the surficial aquifer system will be partly discussed based on these land resource provinces. Land resource provinces in the study area are the Central Florida Ridge, Coastal Flatwoods, Sand Hills, Southern Coastal Plain, and Southern Piedmont (fig. 2). The Central Florida Ridge, Coastal Flatwoods, and Southern Coastal Plain are the major land resource provinces in the study area and discussion will be limited to them in this report.

The Central Florida Ridge comprises much of the central uplands of Florida. This area is characterized by hills, ridges, terraces, and many lakes, and is marked by karst topography--numerous sinks, sinkhole 


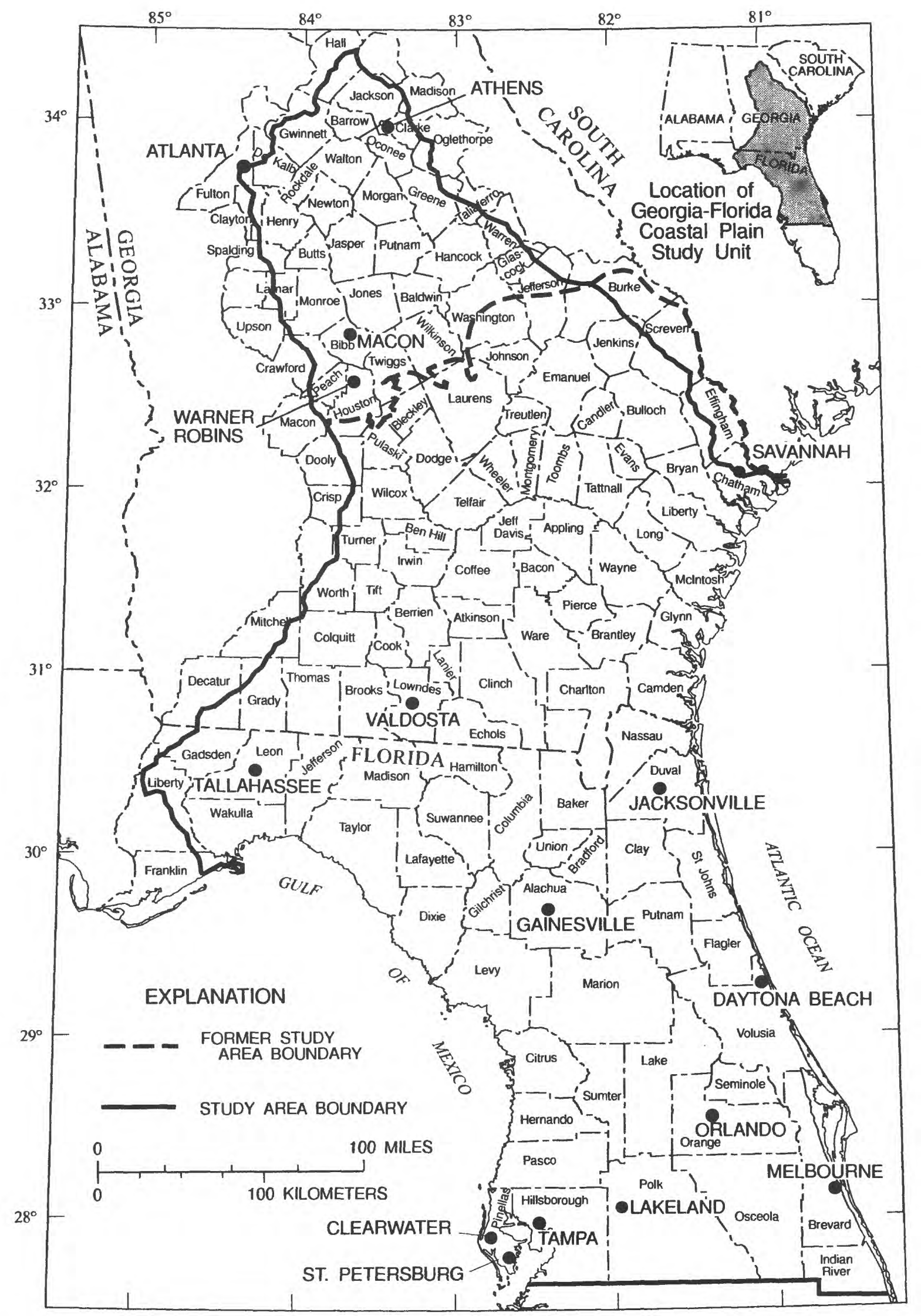

Figure 1. Location of Georgia-Florida Coastal Plain study area. 


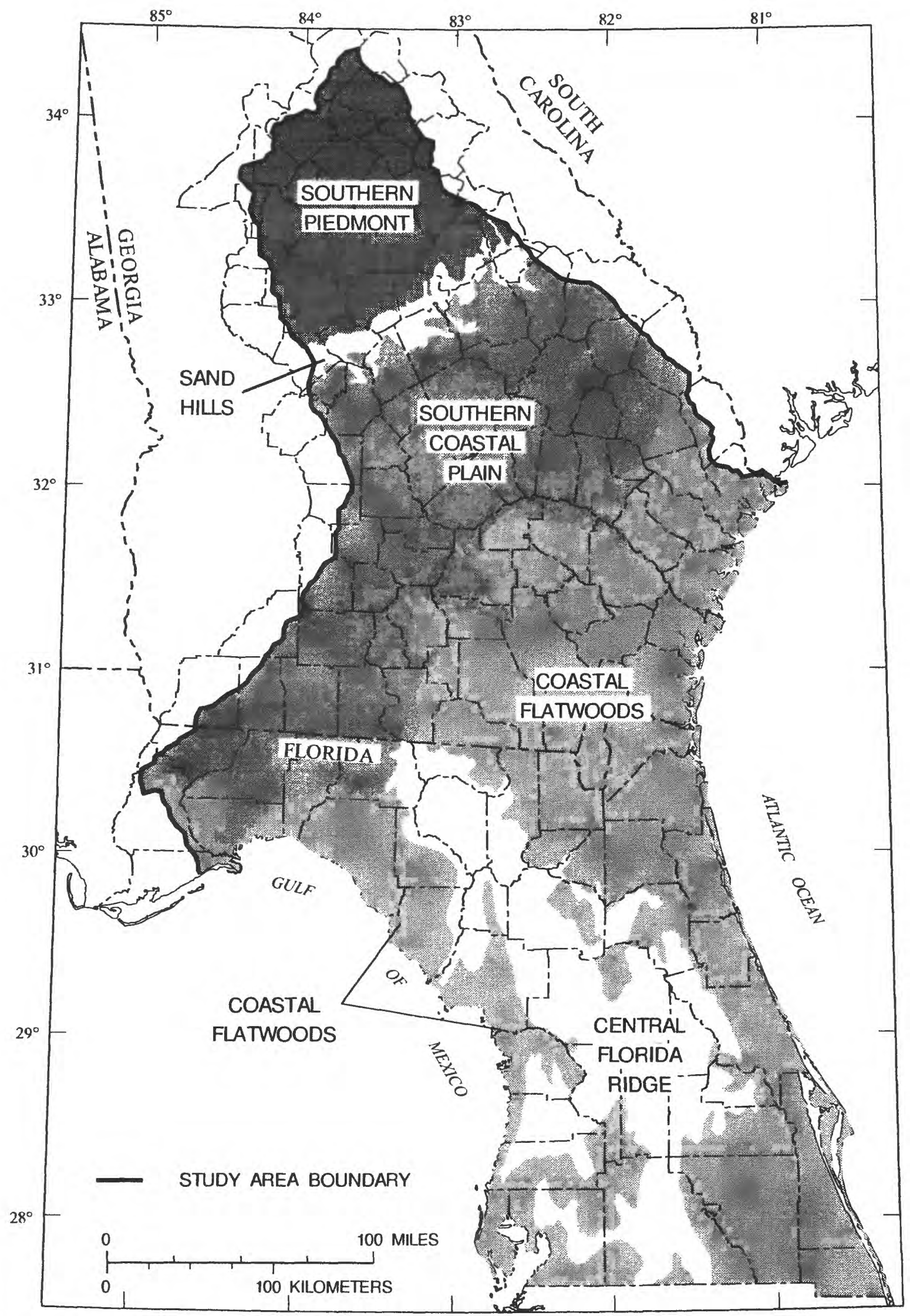

Figure 2. Land resource provinces in the Georgia-Florida Coastal Plain. 
lakes, sinking streams, and springs. Some parts of the area have very few streams, with most of the rainfall recharging ground water. Soils in this province are sloped and excessively well drained (Caldwell and Johnson, 1982). The Coastal Flatwoods area includes the coastal areas of Georgia and Florida, and consists of nearly level plains and marshes, along with a set of low terraces. Soils in this province are nearly level and moderately to well drained (Caldwell and Johnson, 1982). The Southern Coastal Plain consists of broad interstream areas with gentle and deeply-incised valleys. Soils are sloped in this province and poorly to moderately drained (Caldwell and Johnson, 1982).

\section{Hydrogeologic Setting}

The primary source of water in the study area is the Floridan aquifer system, which is one of the major sources of ground-water supply in the nation. Other aquifers present in the study area include the surficial aquifer system, intermediate aquifer system, Brunswick aquifer, Claiborne aquifer, Cretaceous aquifer system, and Crystalline rock aquifers (table 1).

Nearly 95 percent of the ground water in the study area is withdrawn from the Floridan aquifer system. The aquifer system is highly productive, and is composed of a sequence of carbonate (limestone and dolomite) rocks that include units of high permeability

Table 1. Description of major aquifers in the Georgia-Florida Coastal Plain

[from Miller, 1990, Clarke and Pierce, 1985, and McFadden and Perriello, 1983]

\begin{tabular}{|c|c|c|c|c|}
\hline \multirow{2}{*}{ System } & \multirow{2}{*}{ Series } & \multicolumn{2}{|c|}{ Aquifer } & \multirow{2}{*}{ Description } \\
\hline & & Florida & Georgia & \\
\hline Quaternary & $\begin{array}{l}\text { Recent to } \\
\text { Pleistocene }\end{array}$ & $\begin{array}{l}\text { Surficial } \\
\text { aquifer } \\
\text { system }\end{array}$ & $\begin{array}{l}\text { Unnamed } \\
\text { surficial } \\
\text { aquifers }\end{array}$ & $\begin{array}{l}\text { Sand, silt, clay, and shell } \\
\text { units, with minor lime- } \\
\text { stone beds }\end{array}$ \\
\hline \multirow{4}{*}{ Tertiary } & Miocene & $\begin{array}{l}\text { Intermediate } \\
\text { aquifer } \\
\text { system }\end{array}$ & $\begin{array}{l}\text { Brunswick aqui- } \\
\text { fer }\end{array}$ & $\begin{array}{l}\text { Shell, limestone, and sand, } \\
\text { with discontinuous clay } \\
\text { layers }\end{array}$ \\
\hline & Oligocene & \multirow{3}{*}{$\begin{array}{l}\text { Upper } \\
\text { Floridan } \\
\text { aquifer }\end{array}$} & $\begin{array}{l}\text { Upper } \\
\text { Floridan } \\
\text { aquifer }\end{array}$ & $\begin{array}{l}\text { Limestone, } \\
\text { dolomite, and } \\
\text { calcareous sand }\end{array}$ \\
\hline & Eocene & & $\begin{array}{l}\text { Claiborne } \\
\text { aquifer }\end{array}$ & $\begin{array}{l}\text { Sand and sandy } \\
\text { limestone }\end{array}$ \\
\hline & Paleocene & & & \\
\hline Cretaceous & & & $\begin{array}{l}\text { Cretaceous } \\
\text { aquifer } \\
\text { system }\end{array}$ & Sand and gravel \\
\hline $\begin{array}{l}\text { Paleozoic to } \\
\text { Precambrian }\end{array}$ & & & $\begin{array}{l}\text { Crystalline } \\
\text { rock aquifers }\end{array}$ & $\begin{array}{l}\text { Granite, gneiss, schist, and } \\
\text { quartzite }\end{array}$ \\
\hline
\end{tabular}


(aquifers) as well as units of low permeability (confining units). The rocks that make up this aquifer system begin as a thin band of bedrock exposed at the surface in southwestern and central Georgia and thicken in a southeasterly direction to a thickness of nearly $3,000 \mathrm{ft}$ along parts of the southern boundary of the study area. The poorly consolidated carbonate rocks of this aquifer system are easily eroded and dissolved by downwardpercolating water. The permeability of the aquifer system is derived from small openings such as solution widened joints as well as large cavernous openings in karst areas. Karst areas are present in much of northern and central Florida and are characterized by numerous caves, sinkholes, and other types of solution openings (Bush and Johnston, 1988). Twenty-five first magnitude springs (flow greater than 100 cubic feet per second) are also located in this area (Rosenau and others, 1977).

A confining unit overlies the Floridan aquifer system over much of its extent. This confining unit includes several aquifers of limited areal extent. The aquifer system is considered confined where the confining unit is greater than $100 \mathrm{ft}$ thick, semiconfined where the confining unit is less than $100 \mathrm{ft}$ thick and may be breached, and unconfined where the unit is virtually absent and the Floridan aquifer system is at or near land surface (fig. 3) (Miller, 1986). A confining unit is also present in the middle of the Floridan aquifer system over most of its extent, hydraulically separating the system into the Upper and Lower Floridan aquifers. In places, no middle confining unit exists and the aquifer system is known as the Upper Floridan aquifer. The ground-water quality data from this aquifer system discussed in this report is from the Upper Floridan aquifer.

The surficial aquifer system and unnamed surficial aquifers overlie the Upper Floridan aquifer and form part of its confining unit in areas where the Upper Floridan aquifer is semiconfined and confined (fig. 3). The surficial aquifer system is an important source of water supply for domestic use when depths to the underlying Upper Floridan aquifer make the cost of drilling and withdrawing water prohibitive or where the Upper Floridan aquifer contains nonpotable water. Units that make up the surficial aquifer system throughout the study area range in age from late Miocene to Holocene age (Miller, 1990) and generally consist of sand, silt, clay and shell units, with some minor limestone beds. The thickness of the surficial aquifer system is generally less than $50 \mathrm{ft}$, but its thickness can be much greater in eastern, coastal areas of the study area. Thicknesses of 100 to $200 \mathrm{ft}$ are common in the southeastern part of the study area (Schiner and others, 1988).

Other aquifers in the study area include the intermediate aquifer system, Brunswick aquifer, Claiborne aquifer, Cretaceous aquifer system, and Crystalline rock aquifers. The intermediate aquifer system and Brunswick aquifer are names given to the same deposits of Miocene age (table 1) that overlie the Upper Floridan aquifer and act as the confining unit. Where permeable layers exist in these aquifers they are utilized as a water supply. The intermediate aquifer system and Brunswick aquifer consist of shell, limestone, and sand with discontinuous clay layers. The Claiborne aquifer underlies the Upper Floridan aquifer in the western part of the study area in Georgia. Deposits in this aquifer are Eocene age and consist of sand and sandy limestone (table 1). The Cretaceous aquifer system underlies the Claiborne aquifer in the central part of Georgia and consists of sand and gravel with discontinuous clay layers (Clarke and Pierce, 1985). Crystalline rock aquifers occur in the northern part of the study area, north of the northernmost extent of the Floridan aquifer system. These aquifers are not laterally extensive and consist of granite, gneiss, schist, and quartzite of late Paleozoic to Precambrian age (table 1). Waterbearing units are located in the regolith and in joints and fractures (Clarke and Pierce, 1985).

\section{Climate}

The climate in the study area ranges from temperate in north-central Georgia to subtropical in central Florida and along the Gulf Coast. Climatic conditions within the study area vary seasonally, annually, and geographically and, in some areas, are primarily influenced by proximity to the Gulf of Mexico and the Atlantic Ocean. Mean annual temperatures range from about 61.3 degrees Fahrenheit ( ${ }^{\circ} \mathrm{F}$ ) in Atlanta, Ga. (Owenby and Ezell, 1992b), in the northern part of the study area, to about $72.4^{\circ} \mathrm{F}$ in St. Petersburg, Fla., in the southwestern part of the study area (Owenby and Ezell, 1992a).

Long-term average rainfall varies from about 44 inches per year in Tampa, Fla. to over 65 inches per year in Tallahassee, Fla. (table 2). The long-term average for south Georgia and Florida is about 53 inches 


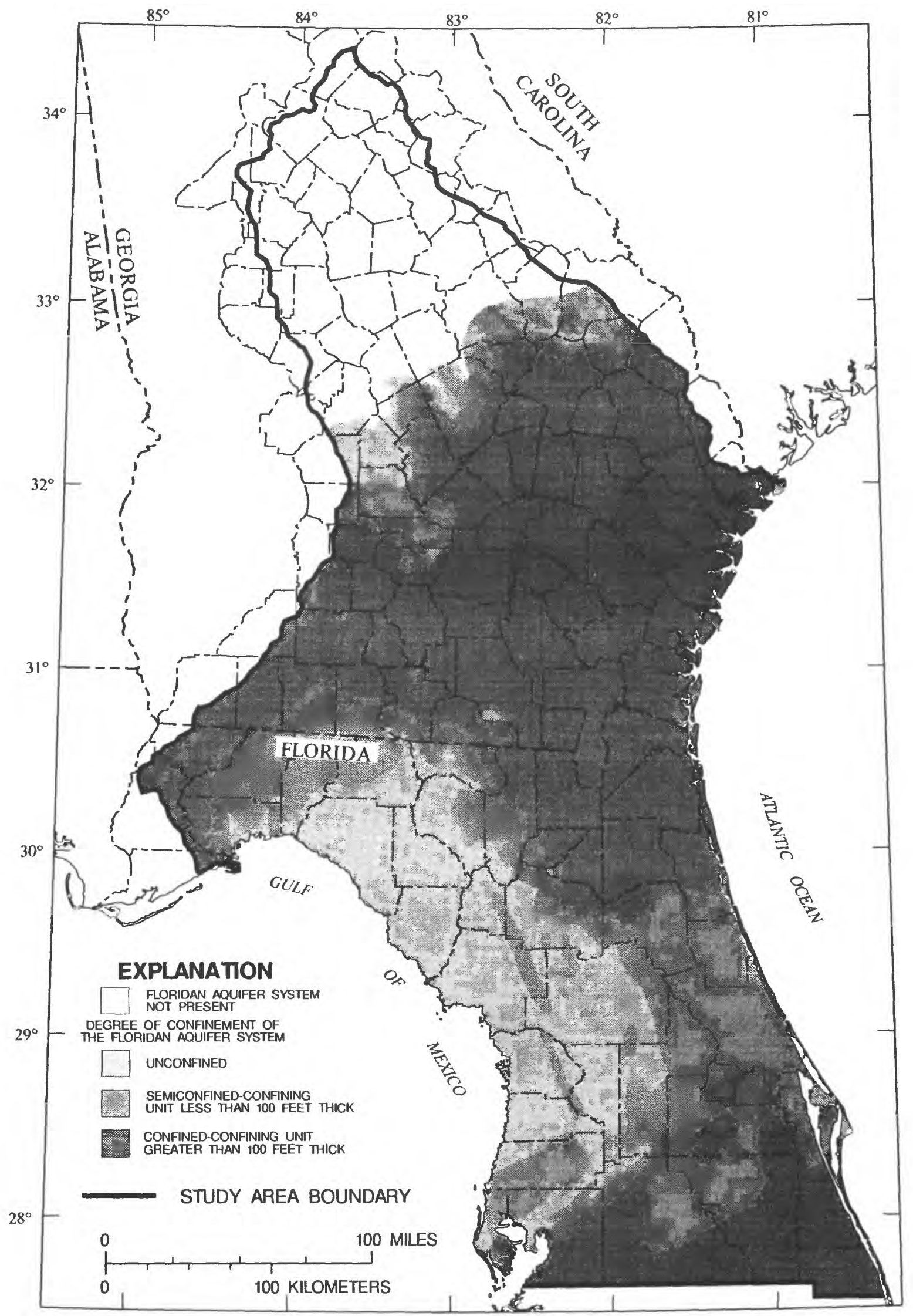

Figure 3. Areas of confined, semiconfined, and unconfined conditions for the Floridan aquifer sytem in the GeorgiaFlorida Coastal Plain. 
per year (Bush and Johnston, 1988, p. 34). In central Florida over half of the rainfall occurs during June through September (Bradley, 1972).

Table 2. Long-term average temperature and rainfall for selected cities in the Georgia-Florida Coastal Plain, 1961-90

[Owenby and Ezell, 1992a, and Owenby and Ezell, 1992b]

\begin{tabular}{lcc}
\hline \multicolumn{1}{c}{ Location } & $\begin{array}{c}\text { Average } \\
\text { temperature } \\
\text { 1961-90, in } \\
\text { degrees } \\
\text { Fahrenheit }\end{array}$ & $\begin{array}{c}\text { Average } \\
\text { rainfall 1961-90, } \\
\text { in inches per } \\
\text { year }\end{array}$ \\
\hline Athens, Ga. & 61.7 & 49.7 \\
Atlanta, Ga. & 61.3 & 50.8 \\
Macon, Ga. & 64.4 & 44.6 \\
Savannah, Ga. & 66.3 & 49.2 \\
Daytona Beach, Fla. & 70.4 & 47.9 \\
Gainesvillc, Fla. & 68.6 & 51.8 \\
Jacksonville, Fla. & 68.0 & 51.3 \\
Melbourne, Fla. & 71.9 & 45.5 \\
Orlando, Fla. & 72.3 & 48.1 \\
Tallahassee, Fla. & 67.2 & 65.7 \\
Tampa, Fla. & 72.4 & 43.9 \\
\hline
\end{tabular}

\section{Population and Land Use}

The population of the study area in 1990 was approximately 9.3 million (Akioka, 1992 and University of Florida, 1991a). Much of the population is concentrated in several major cities in Georgia and Florida. In Georgia, major cities are Athens, Macon, Savannah, Valdosta, Warner Robins, and parts of metropolitan Atlanta (fig. 1). In Florida, major cities include Clearwater, Daytona Beach, Gainesville, Jacksonville, Lakeland, Melbourne, Orlando, St. Petersburg, Tallahassee, and Tampa (fig. 1).

Data from the USGS classification system for land use and land cover (Anderson and others, 1976; Mitchell and others, 1977) was used with some modifications to determine the locations of various land uses and general proportions of land use and land cover in the study area. This designation of land use and land cover was compiled in the mid-1970's at a national scale. General land use and land cover in the study area include urban or built-up land, agricultural land, rangeland, forest land, water, wetland, and barren land (Anderson and others, 1976). Agricultural land and rangeland were combined for this report and classified as agricultural. Barren land use includes mines, quarries, and beaches. The percentages of land area in the study area in each of the major land use categories are listed in table 3. The geographical extent of the urban, forest, and agricultural land use areas are shown in figures 4,5 , and 6 .

Table 3. Land-use percentages in the Georgia-Florida Coastal Plain

\begin{tabular}{lc}
\hline \multicolumn{1}{c}{$\begin{array}{c}\text { Land-use } \\
\text { classification }\end{array}$} & $\begin{array}{c}\text { Percent of study area } \\
\text { covered, 1972-78 }\end{array}$ \\
\hline Forest & 47.9 \\
Agricultural and rangeland & 27.8 \\
Wetland & 15.8 \\
Urban & 4.4 \\
Water & 2.7 \\
Barren & 1.4 \\
\hline
\end{tabular}

Forest areas, much of which are in silviculture, account for approximately 48 percent of the study area (fig. 5). Dominant trees in the study area include loblolly, shortleaf, longleaf, slash, and pond pines and some deciduous oaks, mostly turkey oaks (Fernald and Purdum, 1992 and Hodler and Schretter, 1986). In Georgia, the highest production of pulpwood in 1989 was in Appling, Charlton, Clinch, Echols, Glynn, Long, Lowndes, Ware, and Wayne Counties (Akioka, 1992, p. 265-68). In Florida, the highest production of pulpwood was in Alachua, Baker, Bradford, Clay, Columbia, Levy, Nassau, and Taylor Counties (University of Florida, 1991b, p. 293-94). National forests are located in parts of Columbia, Baker, Leon, Liberty, Marion, and Wakulla Counties in Florida, and in parts of Greene, Jasper, Jones, and Putnam Counties in Georgia.

Agricultural areas account for nearly 28 percent of the study area, are concentrated in several areas, and include growing of field crops, fruits (including citrus), vegetables and cattle, dairy and poultry operations (fig. 6). Field crops grown in the study area include corn, cotton, peanuts, sorghum, soybeans, tobacco, and wheat. (Florida Agricultural Statistics Service, 1991). Central and northern Florida and southern Georgia produce a wide variety of crops because of the relatively flat terrain, warm climate, sandy soils, proximity to markets, and availability of water for irrigation purposes (R.L. Marella, U.S. Geological Survey, written commun., 1994). Fruit crops are dominated by citrus production which occupies nearly 250,000 acres and is heavily concentrated in Hillsborough, Indian River, and Polk Counties in Florida (Florida Agricultural Statistics Service, 1992a). Many vegetables are also grown in the study 




Figure 4. Urban land-use areas in the Georgia-Florida Coastal Plain. 


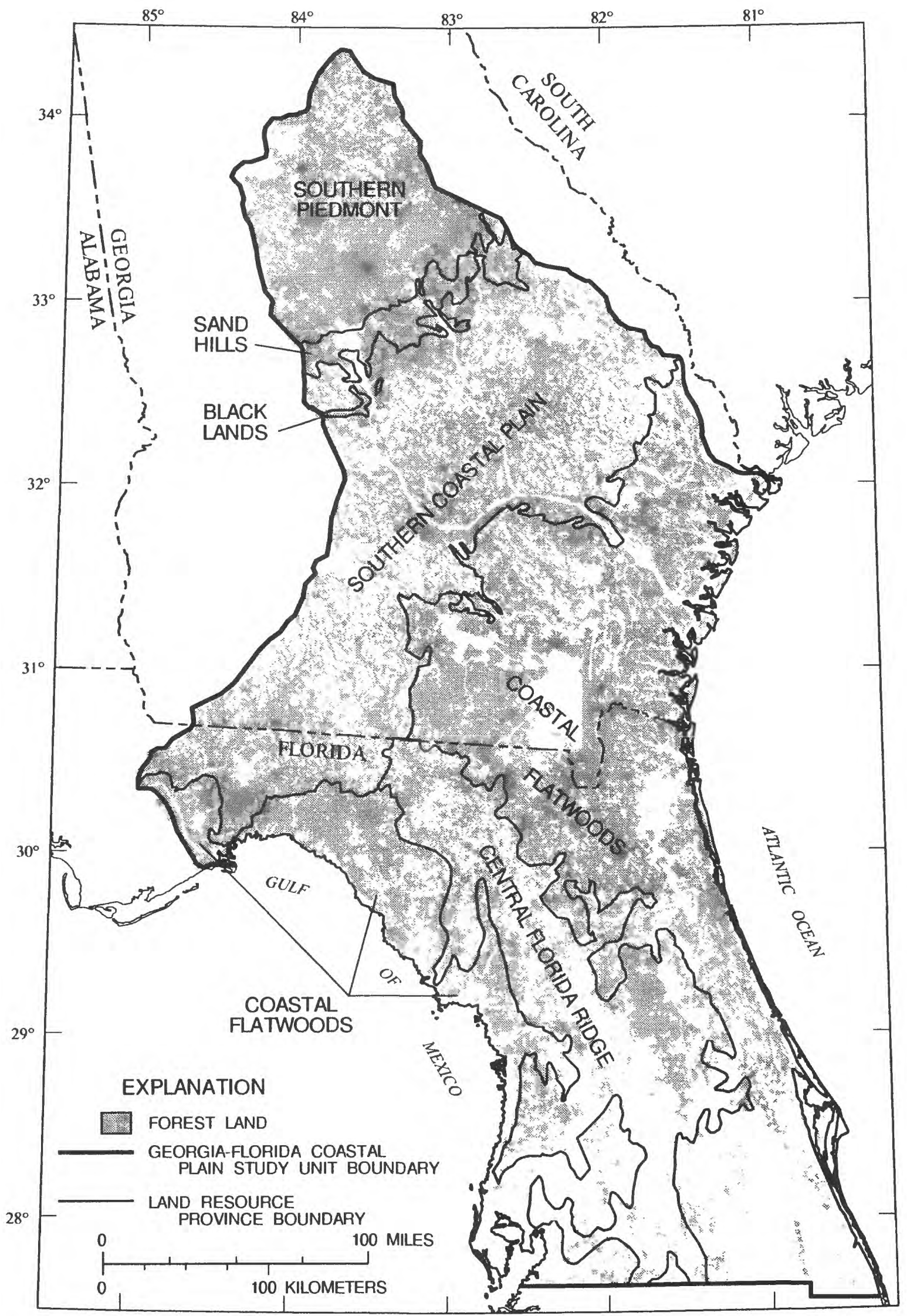

Figure 5. Forest land-use areas in the Georgia-Florida Coastal Plain. 


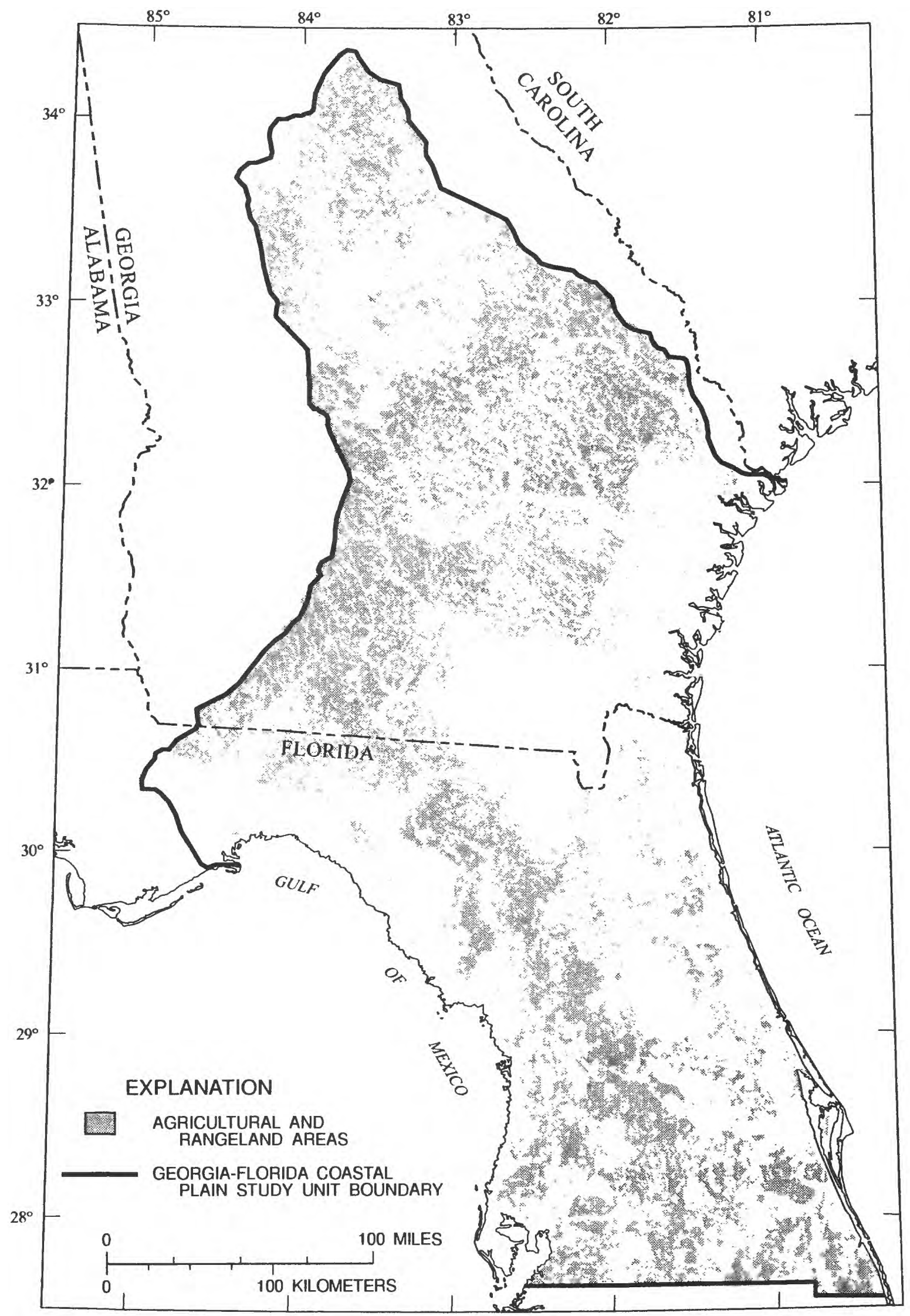

Figure 6. Agricultural land-use areas in the Georgia-Florida Coastal Plain. 
area including cabbage, carrots, celery, cucumbers, green peppers, lima beans, onions, potatoes, snap beans, sweet corn, and tomatoes. Vegetable-growing areas in Florida are primarily in Flagler, Lake, Orange, Putnam, and St. Johns Counties (Florida Agricultural Statistics Service, 1992c). In Georgia, vegetables are primarily grown in Colquitt, Crisp, Decatur, Macon, Mitchell, Tift, and Turner Counties. Large numbers of livestock, dairy, and poultry farms are also present in the study area. These farms are primarily located in Alachua, Baker, Clay, Hillsborough, Gilchrist, Lafayette, Osceola, Polk, Suwannee, and Union Counties in Florida (Florida Agricultural Statistics Service, 1992b) and in Brantley, Colquitt, Hall, Jackson, Jenkins, Macon, Madison, Mitchell, Morgan, and Putnam Counties in Georgia (Georgia Agricultural Statistics Service, 1993).

\section{Sources of Nitrogen and Phosphorus}

Sources of nitrogen and phosphorus input to each county from livestock manure (cows and chickens), fertilizer, septic tanks and atmospheric deposition from rainfall were estimated using data from several national and state data sources. Information concerning manure, fertilizer, and rainfall inputs were available for several years, generally from 1985-90. Estimates of nitrogen and phosphorus inputs were calculated for the study area for 1990 , the only year for which septic tank numbers were readily available.

Estimates of nitrogen and phosphorus inputs from manure were calculated from estimated numbers of beef cows, dairy cows, broiler chickens, and egglaying chickens per county (Florida Agricultural Statistics Service, 1992a, and Georgia Agricultural Statistics Service, 1993) and multiplying each by the estimated contributions of nitrogen and phosphorus per year per beef cow, dairy cow, broiler chicken, and egg-laying hen (R.B. Alexander, U.S. Geological Survey, written commun., 1992). Some proportion of nitrogen and phosphorus from manure is recycled because some animal feed is produced within a county. Estimates of nitrogen inputs from manure were not corrected to take into account losses of nitrogen through volatilization, runoff and seepage (VanDyne and Gilbertson, 1978) during storage, handling and application. These losses could cause the estimated amounts of nitrogen manure inputs to decrease by 25 to 80 percent (Kay and Hammond, 1985).
Estimates of nitrogen and phosphorus inputs from fertilizer were obtained based on data from fertilizer sales by county (J.T. Berry, Tennessee Valley Authority, written commun., 1993). Nitrogen inputs from rainfall were estimated from weekly data for 1990 , using an average nitrogen amount from seven rainfall collection stations of the National Atmospheric Deposition Program located in the study area (Colorado State University, written commun., 1993). Nitrogen and phosphorus inputs from septic tanks were estimated based on the number of septic tanks per county (M. Sik, State of Georgia Office of Planning and Budget, written commun., 1993; U.S. Department of the Census, 1993), the average volume of effluent per day, and the average nitrogen and phosphorus concentrations in septic tank effluent (Tchobanoglous, 1991). The inputs per unit area, in tons per square mile (tons $/ \mathrm{mi}^{2}$ ), for each source by county were determined by dividing the nitrogen and phosphorus inputs per county in tons by the area (in $\mathrm{mi}^{2}$ ) of each county. Nitrogen inputs from rainfall for 1990 were estimated using the average annual sum of nitrogen input from nitrate and ammonia as measured at seven rainfall collection stations located throughout the study area (fig. 7) (Colorado State University, written commun., 1993). Phosphorus inputs from rainfall were not available.

Estimates by county for 1990 for nitrogen inputs from manure, fertilizers, and septic tanks in tons $/ \mathrm{mi}^{2}$ are shown in figure 7 . The counties with the greatest inputs of nitrogen from the three sources were the Georgia counties of Madison (138 tons $/ \mathrm{mi}^{2}$ ), Jackson (105 tons $/ \mathrm{mi}^{2}$ ), and Hall ( 74 tons $/ \mathrm{mi}^{2}$ ). The greatest nitrogen inputs in 1990 were from livestock manure. The greatest nitrogen inputs from manure were in Madison (136 tons $/ \mathrm{mi}^{2}$ ), Jackson (104 tons $/ \mathrm{mi}^{2}$ ), and Hall ( 72 tons $/ \mathrm{mi}^{2}$ ) Counties in Georgia. The greatest nitrogen inputs from fertilizer were in Mitchell ( 15 tons $/ \mathrm{mi}^{2}$ ) and Tift ( 14 tons $\left./ \mathrm{mi}^{2}\right)$ Counties in Georgia. The greatest nitrogen inputs from septic tanks were in Gwinnett $\left(1.7\right.$ tons $\left./ \mathrm{mi}^{2}\right)$ and Fulton $\left(1.5\right.$ tons $\left./ \mathrm{mi}^{2}\right)$ Counties in Georgia. Nitrogen inputs from rainfall ranged from 0.5 to 1.0 tons $/ \mathrm{mi}^{2}$ at the seven stations in 1990 , with an average nitrogen input of 0.77 tons $/ \mathrm{mi}^{2}$.

Phosphorus inputs from manure, fertilizers, and septic tanks for 1990 are shown in figure 8 . The greatest phosphorus inputs were in Madison (43 tons $/ \mathrm{mi}^{2}$ ), Jackson ( 33 tons $/ \mathrm{mi}^{2}$ ), and Hall $\left(23\right.$ tons $\left./ \mathrm{mi}^{2}\right)$ Counties in Georgia. Most of the phosphorus inputs for these three counties were from manure. 


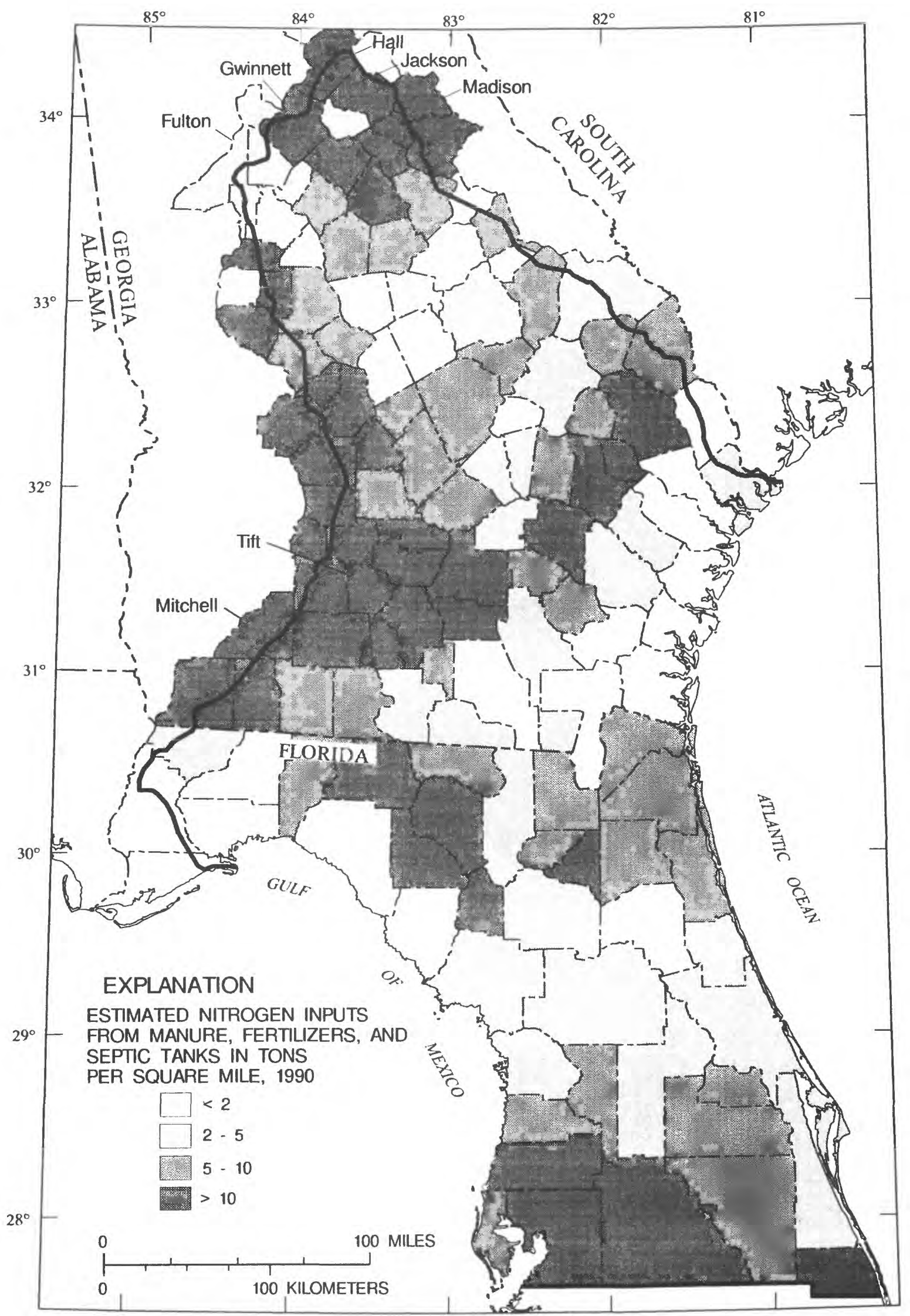

Figure 7. Estimated nitrogen inputs from manure, fertilizers, and septic tanks by county in the Georgia-Florida Coastal Plain, 1990. 


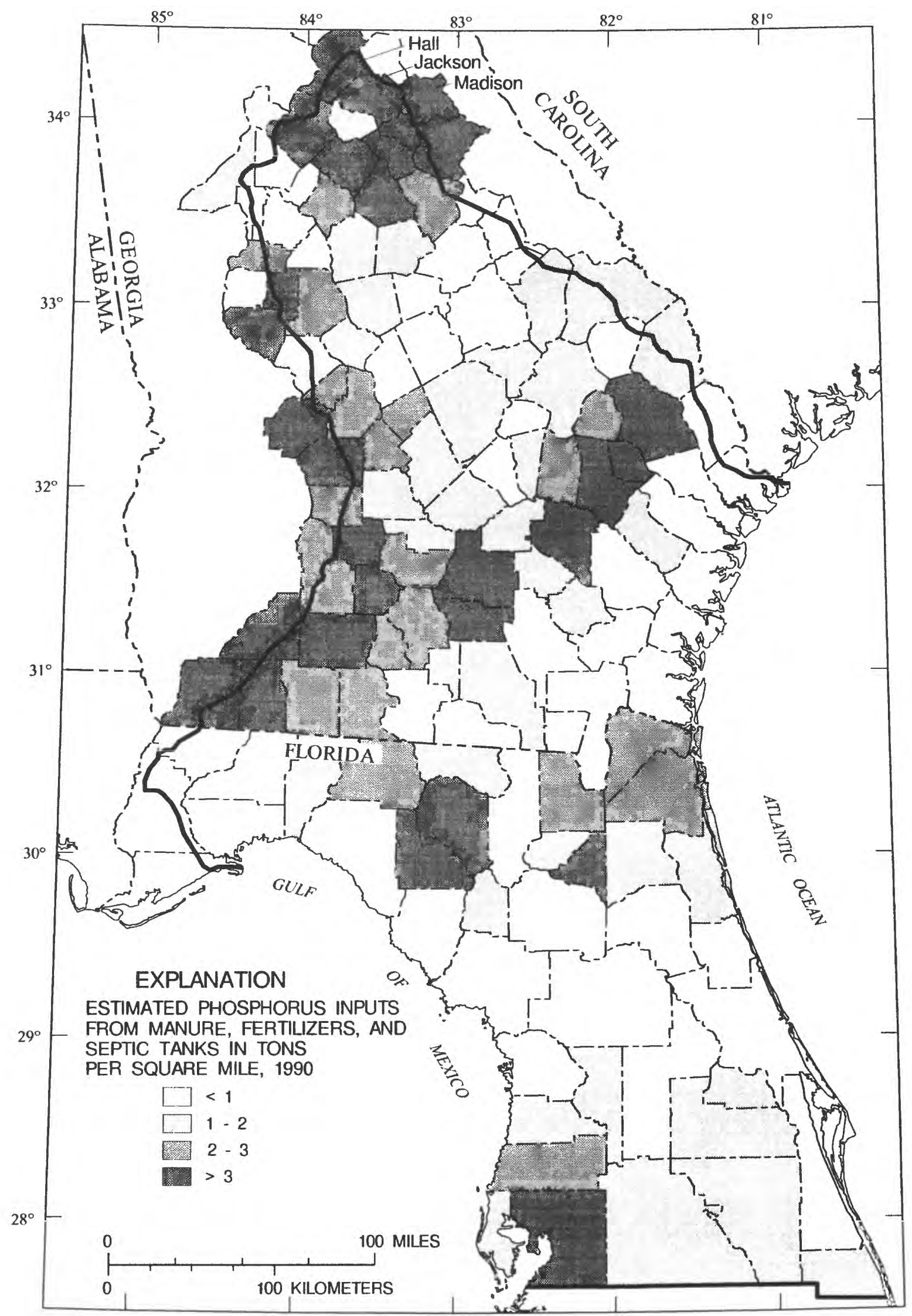

Figure 8. Estimated phosphorus inputs from manure, fertilizers, and septic tanks by county in the GeorgiaFlorida Coastal Plain, 1990. 


\section{Water Use}

Ground water supplies over half of the freshwater used in the study area and supplies most of the water used for drinking supplies. Of 5,082 million gallons per day (Mgal/d) of freshwater withdrawn during 1990, total ground-water withdrawals were 2,895 million gallons per day (Mgal/d) (Marella and Fanning, 1995). In the parts of Florida in the study area, ground-water use was 2,292 $\mathrm{Mgal} / \mathrm{d}$ and in the parts of Georgia in the study area the use was $603 \mathrm{Mgal} / \mathrm{d}$ (Marella and Fanning, 1995). Ground water supplied the drinking water for nearly 77 percent of the population in the study area. Ground-water withdrawals in 1990 varied by county in the study area; some counties withdrew no ground water and Polk County in Florida withdrew the greatest amount from ground water, 353 Mgal/d (fig. 9).

Nearly 91 percent $(2,635 \mathrm{Mgal} / \mathrm{d})$ of the groundwater use during 1990 was supplied by the Upper Floridan aquifer (Marella and Fanning, 1995). The surficial aquifer system and other aquifers supplied about 9 percent of the ground-water withdrawn. These aquifers are utilized for small self-supplied domestic use in areas where the Upper Floridan aquifer is too deep to tap, the water of the Upper Floridan aquifer is nonpotable, or the Upper Floridan aquifer in not present. Withdrawals for public supply and agricultural irrigation in 1990 were generally the highest categories of use, with lesser amounts withdrawn for commercial and industrial supply, self-supplied domestic use, and power generation (fig. 10).

Treated wastewater discharged within the study area was estimated at nearly $1,187 \mathrm{Mgal} / \mathrm{d}$. Of the total water treated, $697 \mathrm{Mgal} / \mathrm{d}$ was discharged directly into surface water and $305 \mathrm{Mgal} / \mathrm{d}$ was discharged to ground water (Marella and Fanning, 1995). Surface-water disposal includes effluent outfalls into bays, rivers, streams, ditches, and wetlands. Ground-water disposal includes effluent discharges through land application systems (spray fields and reuse systems), drain fields, injection wells, and percolation ponds. The largest discharges through land application systems in 1990 occurred in Clayton County, Ga. (14 Mgal/d), and Pinellas (21 Mgal/d), Orange (20 Mgal/d), and Leon (12 Mgal/d) Counties, Fla. (Marella and Fanning, 1995). Estimated discharge from septic tanks in the study area during 1990 were nearly $185 \mathrm{Mgal} / \mathrm{d}$. Most of this water is released to the ground and may percolate into the surficial aquifer system, the unconfined Upper Floridan aquifer, or other unconfined aquifers.

\section{AVAILABLE DATA ON NUTRIENTS IN GROUND WATER}

Ground-water quality data were available from several Federal, State, and local agencies. Data from many agencies were not used because the data were collected for purposes other than general ground-water quality assessment, lacked ancillary data for wells (depths or locations of wells), or had highly localized spatial distribution of sampling sites. Only three major sources of data are included for discussion in this report; the USGS, FDEP, and GGS.

\section{Compilation of Data}

The data sources used in this report are from the water-quality data files of the USGS, the Ground WaterQuality Monitoring Network of the FDEP, and the Coastal Plain Nitrate Survey of the GGS. Because of differences in the types of well sampled, spatial distribution of sampling sites, duration of sampling, and sample collection methods, the data from the three sources are analyzed separately in this report. The types of wells sampled, frequency and spatial distribution of sampling sites, duration of sampling and number of sites sampled within the Georgia-Florida Coastal Plain are described in table 4.

Table 4. Description of sources of selected nitrogen and phosphorus data for ground water in the Georgia-Florida Coastal Plain

\begin{tabular}{|c|c|c|c|c|}
\hline Agency, Program & $\begin{array}{l}\text { Number of wells } \\
\text { sampled in study } \\
\text { area }\end{array}$ & $\begin{array}{l}\text { Type of well } \\
\text { sampled }\end{array}$ & $\begin{array}{c}\text { Spatial } \\
\text { distribution of } \\
\text { wells sampled }\end{array}$ & Duration of sampling \\
\hline $\begin{array}{l}\text { U.S. Geological Survey, National Water } \\
\text { Information System }\end{array}$ & 1,309 & $\begin{array}{l}\text { Mostly } \\
\text { monitoring }\end{array}$ & $\begin{array}{l}1,167 \text { sites in } \\
\text { Florida, } 142 \text { sites } \\
\text { in Georgia }\end{array}$ & $\begin{array}{l}\text { January 1972- October } \\
1990^{1}\end{array}$ \\
\hline $\begin{array}{l}\text { Florida Department of Environmental } \\
\text { Protection, Ground Water Quality } \\
\text { Monitoring Network }\end{array}$ & 831 & $\begin{array}{l}\text { Mostly } \\
\text { monitoring }\end{array}$ & $\begin{array}{l}\text { Statewide in } \\
\text { Florida }\end{array}$ & $\begin{array}{l}\text { March } 1985 \\
\text { October } 1990^{1}\end{array}$ \\
\hline $\begin{array}{l}\text { Georgia Geologic Survey, Coastal Plain } \\
\text { Nitrate Study }\end{array}$ & 680 & Domestic & $\begin{array}{l}\text { Coastal plain of } \\
\text { Georgia }\end{array}$ & $\begin{array}{l}\text { January } 1990- \\
\text { December } 1992^{2}\end{array}$ \\
\hline
\end{tabular}

\footnotetext{
1 Data collected after this date were excluded.

2 Data were included after October 1990 because little data were collected in the Georgia part of the study area.
} 


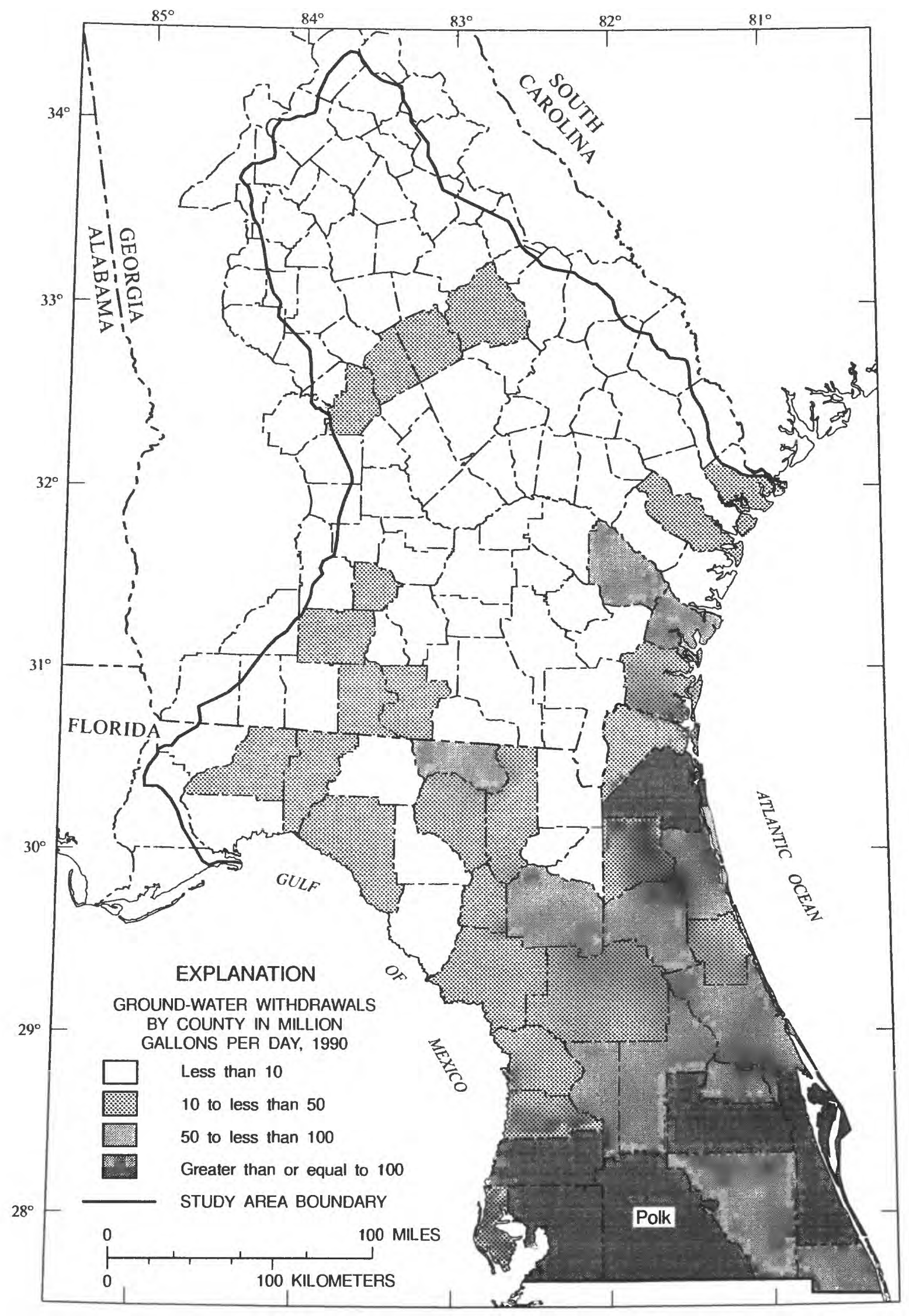

Figure 9. Ground-water withdrawals by county in the Georgia-Florida Coastal Plain, 1990. 


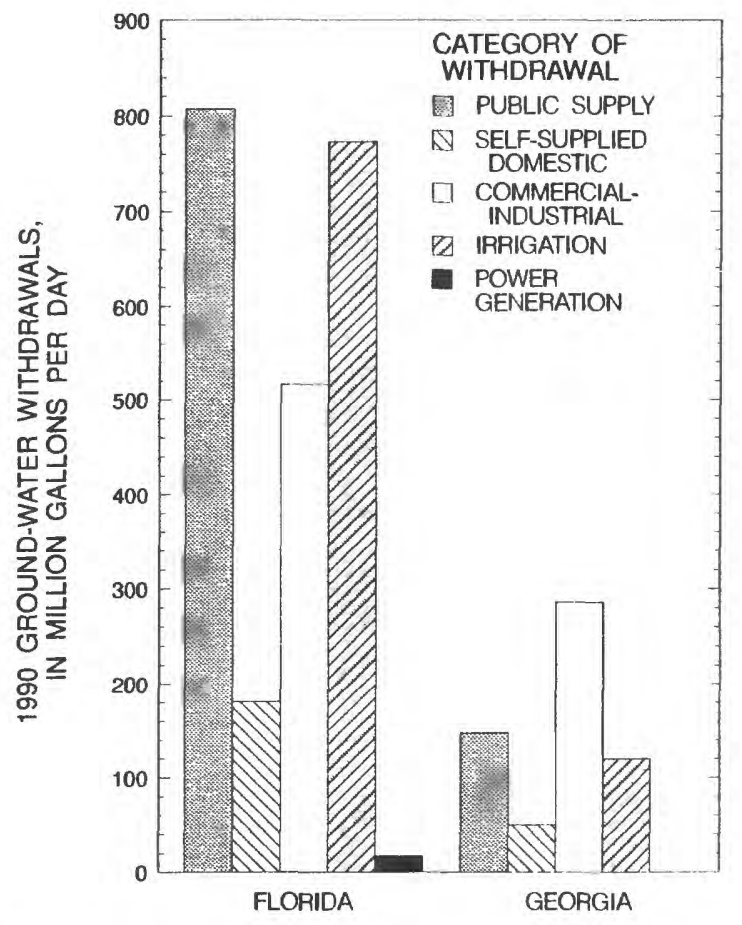

Figure 10. Ground-water withdrawals by State and by category in the Georgia-Florida Coastal Plain, 1990.
The duration of sampling was different from the three data sources. Data from USGS files were included in this report for the time period January 1972, through October 1990 (fig. 11). The FDEP data sampling dates range from March 1985, through the present (1994), but for this report samples collected after October, 1990 were not included (fig. 11). The GGS data were collected in 1990-92. Data from the GGS collected after October, 1990 were included for analysis for this report because of the limited data in the Georgia part of the study area from other sources.

Data from USGS, FDEP, and GGS data sources were screened to eliminate wells where depth or aquifer information was missing. USGS and FDEP data contained minimal samples from wells completed in aquifers other than the Upper Floridan aquifer and surficial aquifer system. Samples from other aquifers were not described in this report. Samples from wells deeper than 1,000 feet were not included for analysis. Aquifer information was not available for the GGS data, but because data in the Georgia part of the study area were extremely limited (table 4), these data were included in this report. Analysis of the GGS data in this report will only consist of descriptive statistics.

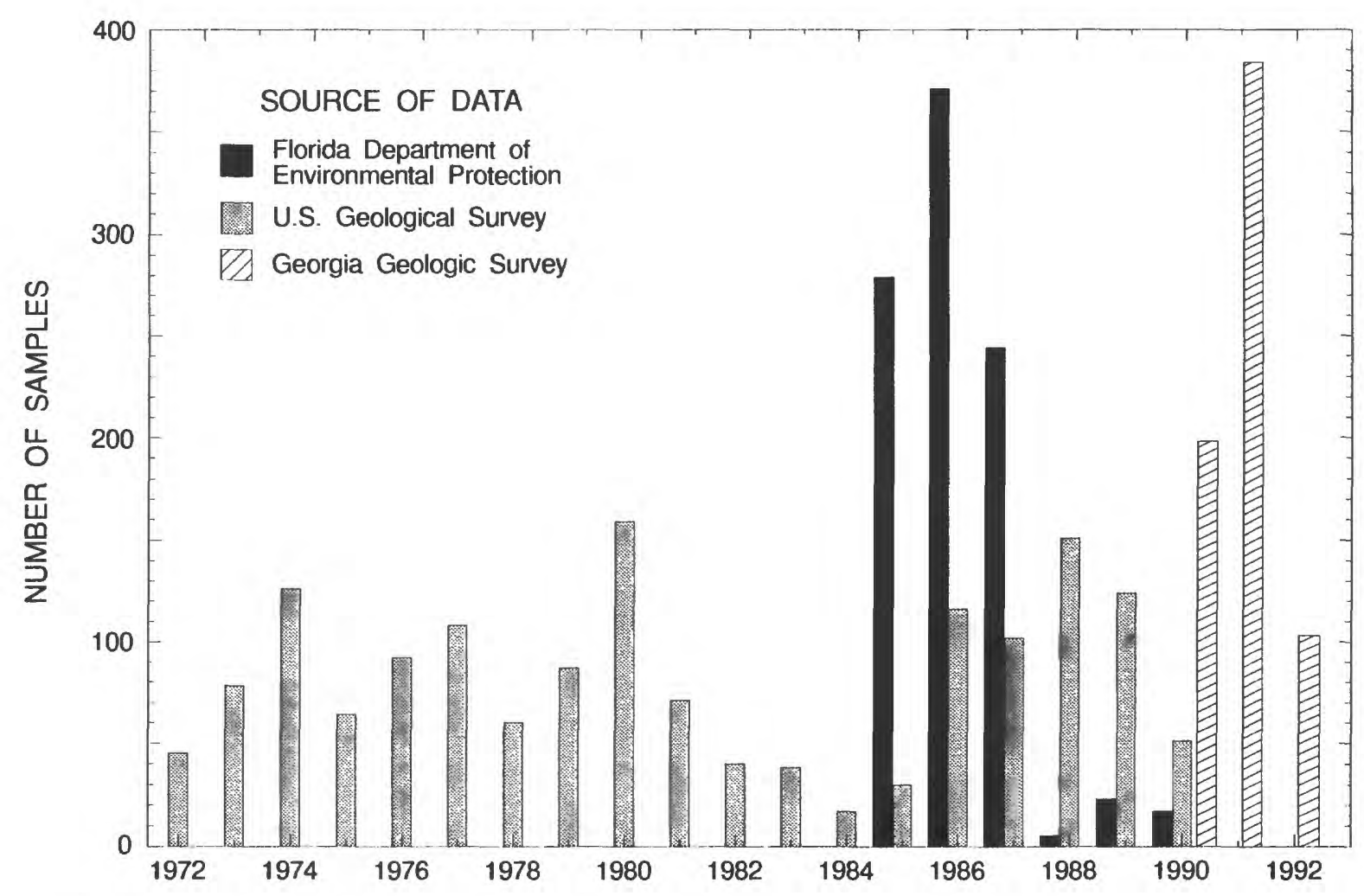

Figure 11. Number of ground-water samples collected per year, 1972-92, from three data sources in the Georgia-Florida Coastal Plain. 
For the USGS and FDEP multiple samples from one well were screened and only the most recent analysis was retained, except for samples from six wells for which trends were analyzed on nitrate concentrations for the time period, 1972-91. Only one analysis was used because only one sample per well was desired for the descriptive statistics. The most recent analysis was chosen to obtain most current data for each site. Only one sample per well was available for the GGS data.

Numbers of samples available for each nitrogen and phosphorus species from each data source are presented in Table 5. In the USGS data, nitrate and ammonia were analyzed and reported by multiple parameter codes because of changes in sampling, preservation, and analytical techniques from the early $1970^{\prime} \mathrm{s}$ through 1990. The values reported for nitrate as nitrogen and ammonia as nitrogen in this report were combined from several parameter codes for dissolved and total concentrations. In addition, nitrite concentrations (dissolved and total) were generally less than the detection limit of 0.02 milligrams per liter $(\mathrm{mg} / \mathrm{L})$; therefore concentrations of nitrate as nitrogen and nitrite plus nitrate as nitrogen were combined for the graphical and statistical analyses used in this report. If the nitrite concentrations were greater than the detection limit, then the nitrite concentration was subtracted from the nitrite plus nitrate as nitrogen concentration before it was combined with the nitrate as nitrogen concentration.

Historically, various analytical detection limits were reported for nitrate, ammonia, orthophosphate, and total phosphorus in the USGS and FDEP data. In most cases for this report, the highest detection limit was used. Exceptions were made for nutrients that had a consistent detection limit except for one or two isolated analyses with an unusually high detection limit. In those cases, the one or two analyses with the high detection limit were eliminated, and the lower, more com- mon detection limit was used. The USGS and FDEP data had the same detection limit for orthophosphate $(0.01 \mathrm{mg} / \mathrm{L})$, but different detection limits for nitrate and total phosphorus. Detection limits for nitrate were $0.02 \mathrm{mg} / \mathrm{L}$ and $0.05 \mathrm{mg} / \mathrm{L}$ in the USGS and FDEP data, respectively. Detection limits for total phosphorus were $0.01 \mathrm{mg} / \mathrm{L}$ and $0.10 \mathrm{mg} / \mathrm{L}$ in the USGS and FDEP data, respectively.

\section{Sample Collection Methods}

Methods for the collection and analysis of water samples for the USGS and the FDEP were very similar and conformed to standard USGS methods for sampling (Wood, 1976) and analysis (Fishman and Friedman, 1989). Most of the USGS and FDEP samples were collected after purging the well casing of standing water, and obtaining stable measurements of field parameters (temperature, $\mathrm{pH}$, and specific conductance). After collection, USGS and FDEP samples were shipped on ice to analytical laboratories. Preservation methods for nutrient samples, however, were different for the USGS and FDEP methods. FDEP nutrient samples were preserved with sulfuric acid, whereas USGS nutrient samples were routinely preserved with mercuric chloride. FDEP ground-water sample collection and analysis procedures are included in Quality Assurance Project Plans on file with FDEP (S. Labbie, Florida Department of Environmental Protection, written commun., 1990).

Methods for collection and analysis of water samples for GGS data were similar in some aspects to those of the USGS and FDEP but were different from them in several crucial aspects. Sample collection methods of the GGS, USGS, and FDEP were similar in that measurements were made of field parameters

Table 5. Numbers of ground-water samples with data for selected nitrogen and phosphorus species from three data sources in the Georgia-Florida Coastal Plain

\begin{tabular}{|c|c|c|c|c|c|}
\hline Agency, Program & Nitrate & Ammonia & $\begin{array}{l}\text { Total } \\
\text { Nitrogen }\end{array}$ & $\begin{array}{c}\text { Phosphorus, } \\
\text { ortho-phosphate, } \\
\text { dissolved }\end{array}$ & $\begin{array}{l}\text { Phosphorus, } \\
\text { total }\end{array}$ \\
\hline $\begin{array}{l}\text { U.S. Geological Survey, National Water } \\
\text { Information System }\end{array}$ & $\mathrm{i}, 178$ & 968 & 537 & 522 & 762 \\
\hline $\begin{array}{l}\text { Florida Department of Environmental Protection, } \\
\text { Ground Water Quality Monitoring Network }\end{array}$ & 820 & 32 & $-m$ & 153 & 399 \\
\hline $\begin{array}{l}\text { Georgia Geoiogic Survey, Coastal Plain Nitrate } \\
\text { Survey }\end{array}$ & 680 & - & - & - & -- \\
\hline
\end{tabular}


(temperature, $\mathrm{pH}$, and specific conductance) prior to sample collection. Notable differences in GGS sample collection and USGS and FDEP sample collection are as follows: 1) GGS samples were collected after water had been pumped from wells for a selected number of minutes (M.A. Stuart, Georgia Southern University, written commun., 1993), whereas USGS and FDEP samples were collected after measurements of field parameters were stable; 2) GGS samples were collected using pumps installed in domestic wells which usually have high pumping rates, whereas USGS and FDEP samples were generally collected using sampling pumps with low pumping rates; and 3) determination of nitrate concentrations and concentrations of other major ions was done in the field using portable test kits (M.A. Stuart, Georgia Southern University, written commun., 1993), which generally have higher detection limits than analytical laboratory methods used by the USGS and FDEP and results may not be as accurate as samples analyzed in a laboratory.

\section{Spatial Distribution of Wells}

A large number of wells sampled by the USGS are geographically located in areas of known waterquality problems. Further, more than 90 percent of the USGS wells sampled for nitrogen and phosphorus concentrations were located in the Florida part of the study area. Within Florida, many of the wells sampled were located in urban areas in central Florida (fig. 12). Several areas in Florida had little or no data, including the urban area of Jacksonville in Duval County (fig. 12). Most areas in Georgia had no wells sampled for nitrogen and phosphorus concentrations and most sites in Georgia were in the Valdosta area in Brooks and Lowndes Counties (fig. 12). Many of the areas where sampling density are greatest represent locations of studies on ground-water quality of public supplies, such as in the Valdosta, Georgia area (McConnell and Hacke, 1993) and in the Orlando, Fla. area (Bradner, 1991 ), or studies on ground-water quality as affected by land applications of secondary-treated sewage in Leon County in Florida (Berndt, 1990) and in Pinellas County in Florida (Trommer, 1992) (figs 1 and 12).

The spatial distribution of wells sampled by the FDEP and GGS represent the goals of the sampling programs of each agency. The goals of the FDEP program were to determine background ground-water quality in the major aquifers in Florida. Contaminated sites were avoided as much as possible. Wells in the FDEP data were generally distributed throughout the study area, although north Florida has greater wells density than does other parts of Florida (fig. 13). The goals of the GGS program were to determine water quality in water from domestic wells throughout a designated area in the Coastal Plain. Wells in the GGS data were evenly distributed in the coastal plain in Georgia, but no wells were located in coastal areas or in southeastern Georgia (fig. 13).

The vertical distribution of wells sampled by the three agencies is shown in figure 14. The median depth was $180 \mathrm{ft}$ for wells in the Upper Floridan aquifer in the USGS data, compared to a median depth of $135 \mathrm{ft}$ for wells in the Upper Floridan aquifer in the FDEP data. In the surficial aquifer system, the median well depth for USGS wells was $17.4 \mathrm{ft}$, compared to $28.5 \mathrm{ft}$ for FDEP wells (fig. 14). The median depths for all wells in the GGS data was $45 \mathrm{ft}$.

Each well in the data from the three agencies was given a land use classification based on land use data (figs. 4, 5, and 6). The land use classification for some USGS wells were changed when the well description indicated a specific land use different than the land use data. This was done for wells in the USGS data, because the designation of land use and land cover were determined in the mid-1970's and many of the USGS wells were drilled after the mid-1970's and because site descriptions sometimes include land use information. Such changes in category were only made when the site description included land-use information. For example, if a well was classified as being in forest land-use area, but the well description indicated the well was located at a sewage treatment plant or a landfill, the land use designation was changed to urban. These changes were made for 228 of the 1,449 wells from the USGS data ( 15 percent). The FDEP and GGS data did not contain site descriptions that included land use information, thus no changes were made to the land use at the wells for these data sources.

The number of wells located in urban, agricultural, and forest land-use areas was different in the USGS, FDEP, and GGS data. Nearly half of the USGS wells (48 percent) were located in urban areas (fig. 15), with fewer wells in agricultural (24 percent) and forest (15 percent) land-use areas. The FDEP wells were distributed among forest ( 39 percent), agricultural (29 percent), and urban (19 percent) land-use areas. The GGS wells were mostly located in agricultural areas (66 percent) and forest land-use areas (28 percent). 


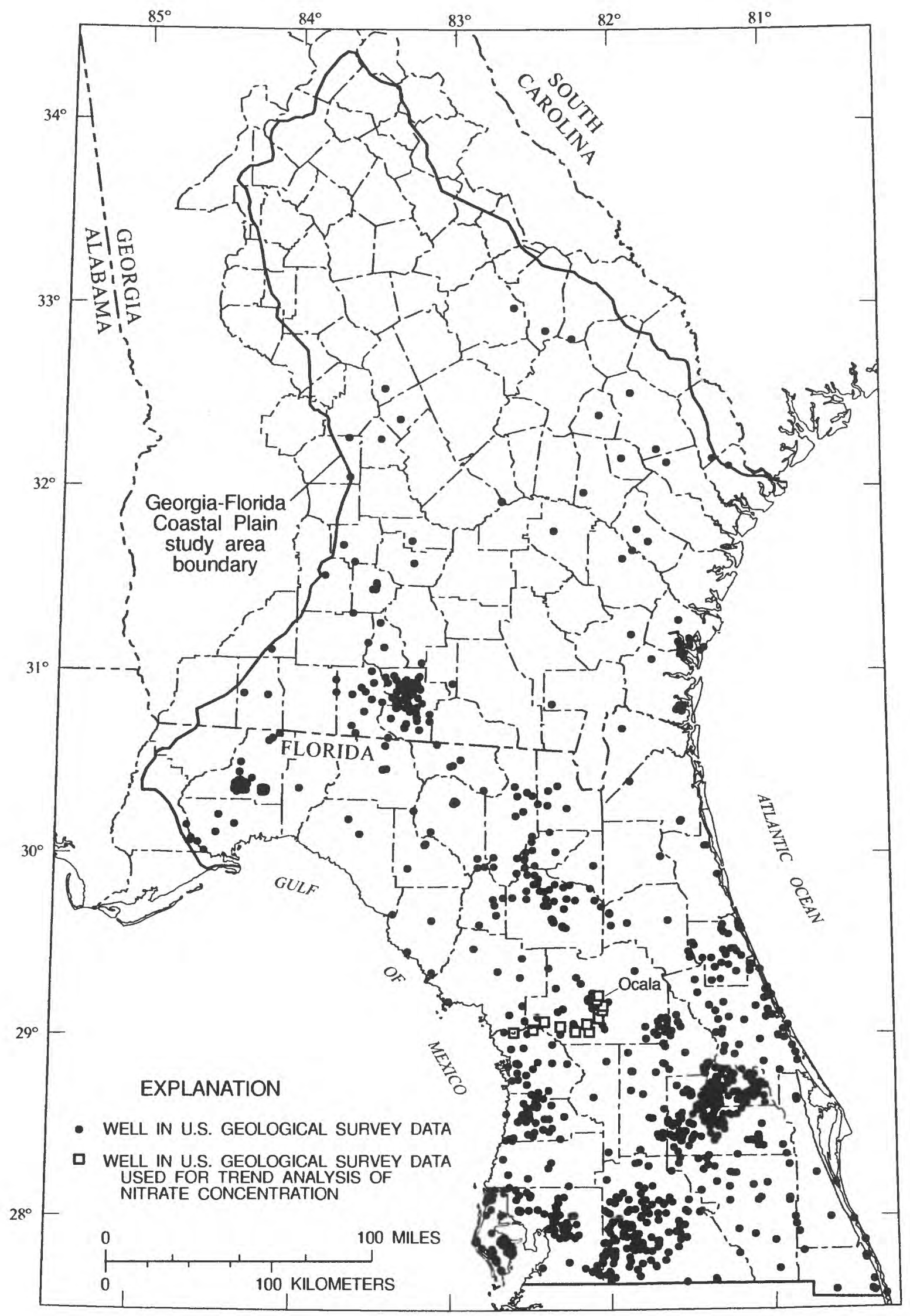

Figure 12. Locations of wells in the U.S. Geological Survey data in the Georgia-Florida Coastal Plain. 


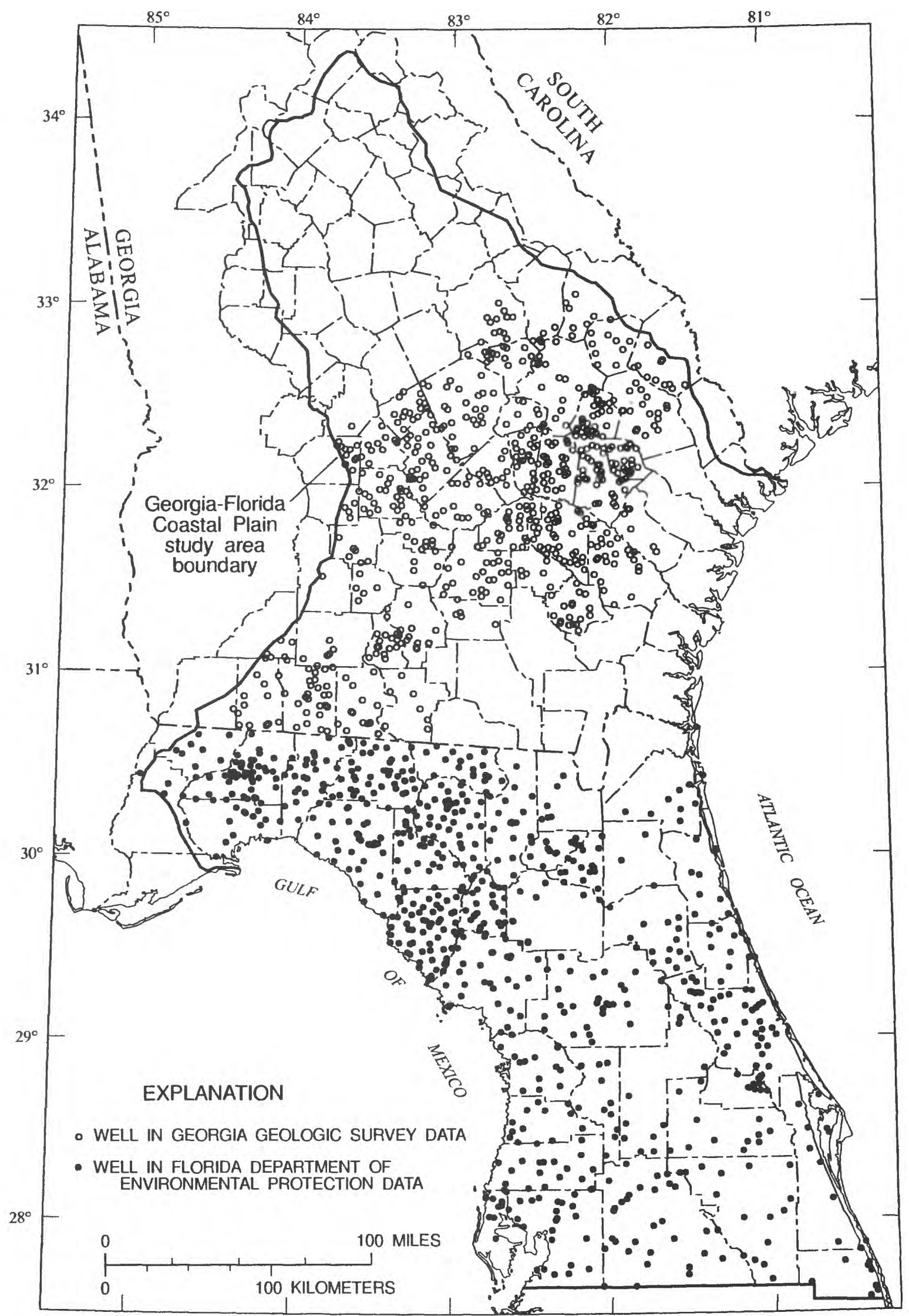

Figure 13. Locations of wells in the Florida Department of Environmental Protection and Georgia Geologic Survey data in the Georgia-Florida Coastal Plain. 


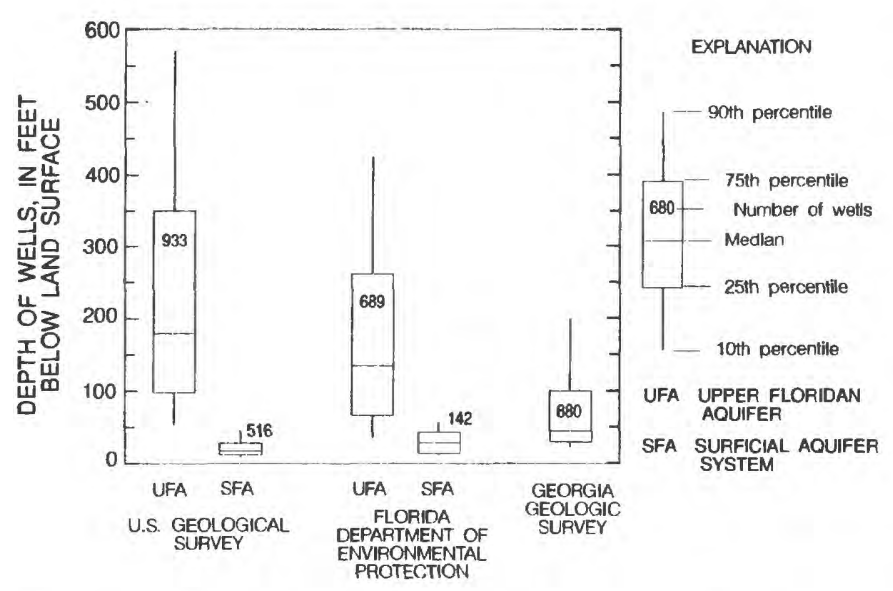

Figure 14. Depth distribution of wells from three data sources.

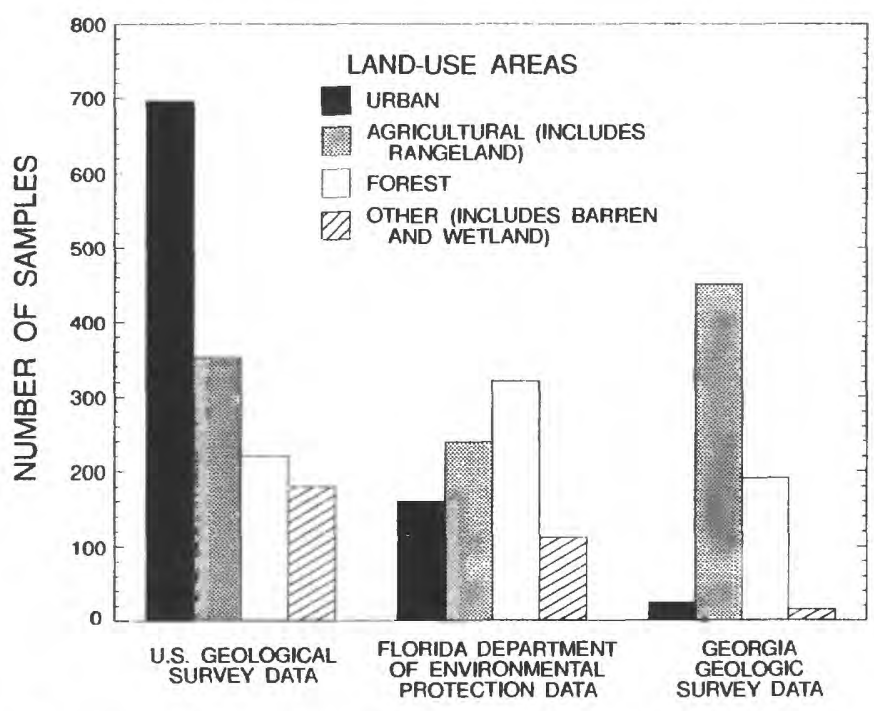

Figure 15. Distribution of samples in various land-use areas from three data sources.

Only 4 percent of the GGS wells were located in urban areas (fig. 15).

\section{DISTRIBUTION OF NUTRIENTS IN GROUND WATER}

The distribution of concentrations of nitrogen and phosphorus species in ground water in this report will be analyzed only for data from the surficial aquifer system and the Upper Floridan aquifer because these two aquifers are utilized the most for water supply. Data from the USGS are discussed for nitrate as nitrogen, ammonia as nitrogen, total nitrogen, orthophosphate, and total phosphorus. Other nitrogen species were available, but were either too limited in sample numbers to be included for discussion, such as organic nitrogen, or concentrations were nearly all below analytical detection limits, such as nitrite as nitrogen. Data from the FDEP were available for many nitrogen and phosphorus species, but only nitrate as nitrogen, orthophosphate, and total phosphorus analyses were present in sufficient numbers to be included for discussion. The only nitrogen or phosphorus species present in the data from the GGS was nitrate as nitrogen. Throughout the remainder of this report nitrate as nitrogen will be referred to as nitrate and ammonia as nitrogen will be referred to as ammonia.

Descriptive and nonparametric statistics are used in this report to summarize the concentrations of nitrogen and phosphorus species in ground water. Boxplots are used to compare the medians and distributions of concentrations of nitrogen and phosphorus species in samples based on categories of land use (agricultural, forest, and urban) (figs. 4-6), hydrogeology (aquifer and thickness of the confining unit of the Upper Floridan aquifer) (fig. 3), and land resource provinces (fig. 2) for the surficial aquifer system. Because only the three major land uses are included in the categories, not all of the samples listed in table 5 will be included in the graphs in the remainder of the report. The nonparametric Mann-Kendall test was used to test for trends in nitrate concentrations in ground water (Helsel and Hirsch, 1992).The nonparametric Wilcoxon rank sum test (SAS Institute, Inc., 1990), was used to test for differences in nitrate concentrations in ground water between some groups of data because the data contain outliers and are not normally or log-normally distributed. This nonparametric technique is not sensitive to the presence of extreme outliers (Ott, 1988 p.183-187). Descriptive statistics, such as median concentrations, for data containing multiple detection limits were determined using probability plotting and maximum likelihood methods designed for water-quality data with multiple detection limits (Helsel'and Cohn, 1988).

\section{Nitrate}

Four ranges of nitrate concentrations were established to assess the effect of land use on ground-water quality (from Madison and Brunett, 1985):

- Less than $0.2 \mathrm{mg} / \mathrm{L}--$ Assumed to represent background concentrations.

- 0.20 to $3.0 \mathrm{mg} / \mathrm{L}$--Transitional; concentrations may or may not represent influence from human activities. 
- 3.01 to $10 \mathrm{mg} / \mathrm{L}--$ May indicate elevated concentrations resulting from human activities.

- More than $10 \mathrm{mg} / \mathrm{L}$--Concentration exceeds maximum contaminant level (MCL) for nitrate as nitrogen in drinking water (U.S. Environmental Protection Agency, 1990).

The frequency distribution of data from the three sources for the four categories defined above are shown in fig. 16. In the samples from the Upper Floridan aquifer, the USGS and the FDEP data had low percentages of samples with nitrate concentrations greater than 3.0 $\mathrm{mg} / \mathrm{L}$ ( 8 and 4 percent, respectively) indicating that few of the nitrate concentrations in samples may have been affected by human activities. In samples from the surficial aquifer system, the USGS data had 20 percent of samples with nitrate concentrations greater than $3.0 \mathrm{mg}$ / $\mathrm{L}$, compared to only 5 percent of the samples in the FDEP data. About 24 percent of the samples in the GGS data were greater than $3.0 \mathrm{mg} / \mathrm{L}$ (fig. 16).

In the USGS data, median nitrate concentrations in ground-water samples were low and few samples had concentrations greater than the MCL of $10 \mathrm{mg} / \mathrm{L}$. Median nitrate concentrations in ground-water samples in the USGS data were similar for the Upper Floridan aquifer and the surficial aquifer system. The median nitrate concentration for 761 samples from Upper Floridan aquifer was $0.05 \mathrm{mg} / \mathrm{L}$ (table 6 ). The median nitrate concentration for 417 samples from the surficial aquifer system was $0.04 \mathrm{mg} / \mathrm{L}$ (table 6). Results of the Wilcoxon ranksum test (SAS Institute, Inc., 1990) indicated that the dif-

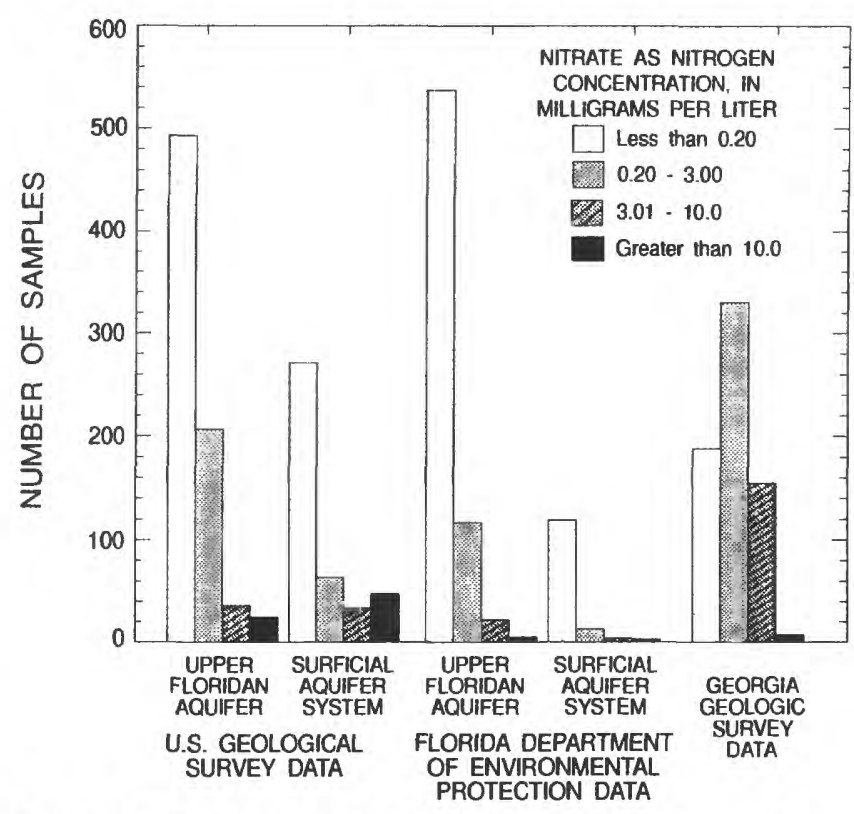

Figure 16. Distribution of nitrate concentrations in groundwater samples from three data sources.

ference in nitrate concentrations in samples from the two aquifers was not statistically significant at the 0.05 significance level $(p$-value $=0.733)$. Of the 761 samples with nitrate concentrations from the Upper Floridan aquifer in the USGS data, only 25 samples ( 3 percent) had concentrations greater than $10 \mathrm{mg} / \mathrm{L}$ (fig. 16). Of 417 nitrate samples from the surficial aquifer system in the USGS data, 48 samples (12 percent) had concentrations greater than $10 \mathrm{mg} / \mathrm{L}$ (fig. 16).

Table 6. Median concentrations of nitrogen and phosphorus species from three data sources in the Georgia-Florida Coastal Plain.

[ $\mathrm{N}=$ number of samples; Medians are concentrations in milligrams per liter]

\begin{tabular}{|c|c|c|c|c|c|c|c|c|c|c|}
\hline & \multicolumn{2}{|c|}{ Nitrate as Nitrogen } & \multicolumn{2}{|c|}{$\begin{array}{c}\text { Ammonia as } \\
\text { Nitrogen }\end{array}$} & \multicolumn{2}{|c|}{ Nitrogen, total } & \multicolumn{2}{|c|}{$\begin{array}{c}\text { Phosphorus, } \\
\text { orthophosphate } \\
\text { dissolved }\end{array}$} & \multicolumn{2}{|c|}{$\begin{array}{c}\text { Phosphorus, } \\
\text { total }\end{array}$} \\
\hline & $\mathrm{N}$ & Median & $\mathrm{N}$ & Median & $\mathrm{N}$ & Median & $\mathrm{N}$ & Median & $\mathbf{N}$ & Median \\
\hline \multicolumn{11}{|c|}{ U.S. Geological Survey } \\
\hline $\begin{array}{l}\text { Upper Floridan } \\
\text { aquifer }\end{array}$ & 761 & 0.05 & 494 & 0.10 & 214 & 0.69 & 341 & 0.02 & 413 & 0.06 \\
\hline $\begin{array}{l}\text { Surficial aquifer } \\
\text { system }\end{array}$ & 417 & 0.04 & 474 & 0.15 & 290 & 1.61 & 181 & 0.03 & 289 & 0.21 \\
\hline \multicolumn{11}{|c|}{ Florida Department of Environmental Protection } \\
\hline $\begin{array}{l}\text { Upper Floridan } \\
\text { aquifer }\end{array}$ & 681 & 0.01 & 9 & 0.28 & - & - & 113 & 0.09 & 373 & 0.10 \\
\hline $\begin{array}{l}\text { Surficial aquifer } \\
\text { system }\end{array}$ & 139 & 0.01 & 23 & 0.27 & - & - & 40 & 0.07 & 23 & 0.10 \\
\hline \multicolumn{11}{|c|}{ Georgia Geologic Survey } \\
\hline All data & 680 & 0.70 & - & - & - & -- & -- & - & -- & - \\
\hline
\end{tabular}




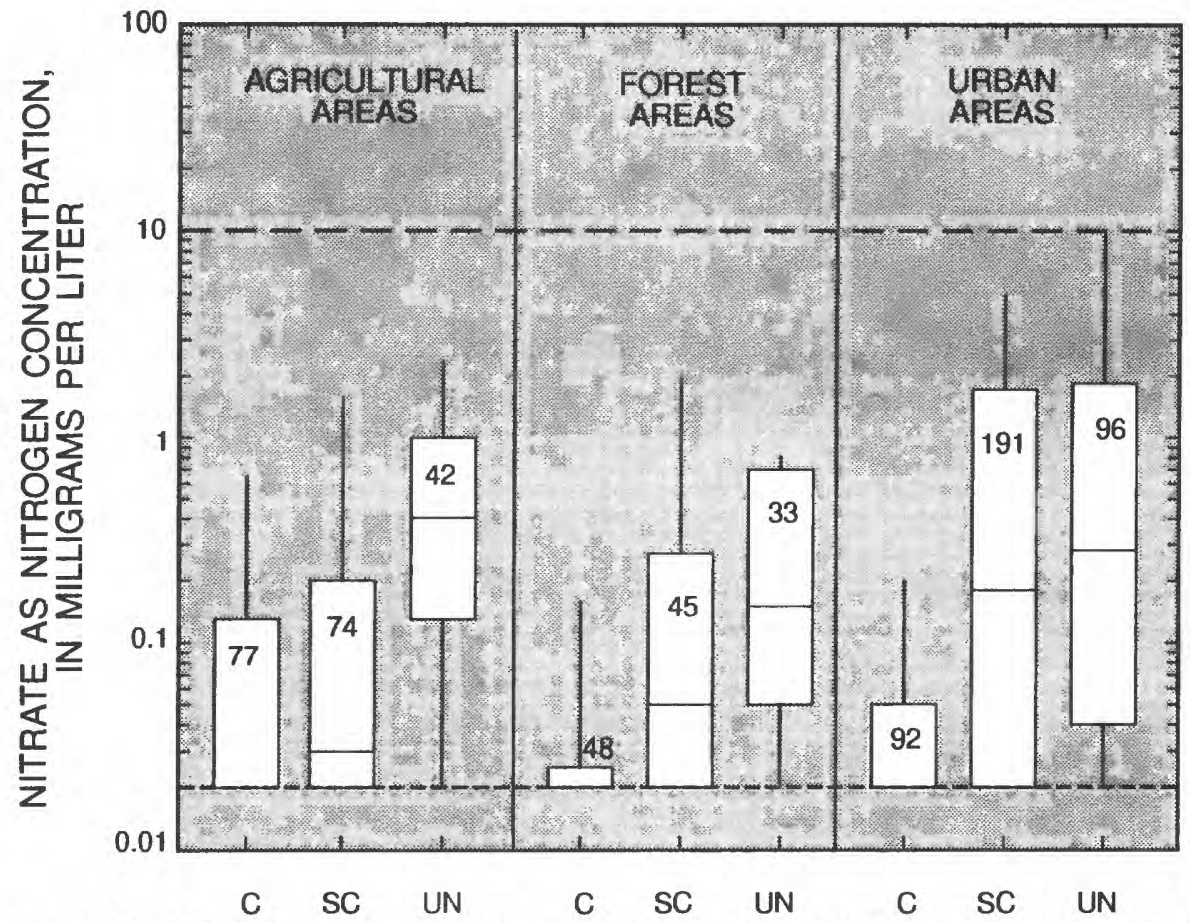

\section{EXPLANATION}

- MAXIMUM CONTAMINANT LEVEL-For drinking water, 10 milligrams per liter. Set by U.S. Environmental Protection Agency.

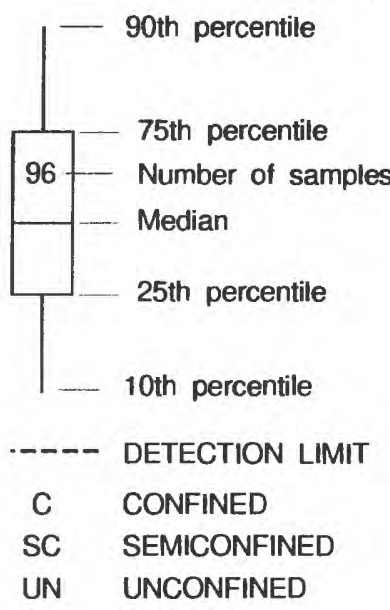

UN UNCONFINED

Figure 17. Nitrate concentrations in water from the Upper Floridan aquifer in confined, semiconfined, and unconfined areas for agricultural, forest, and urban areas in the Georgia-Florida Coastal Plain (U.S. Geological Survey data).

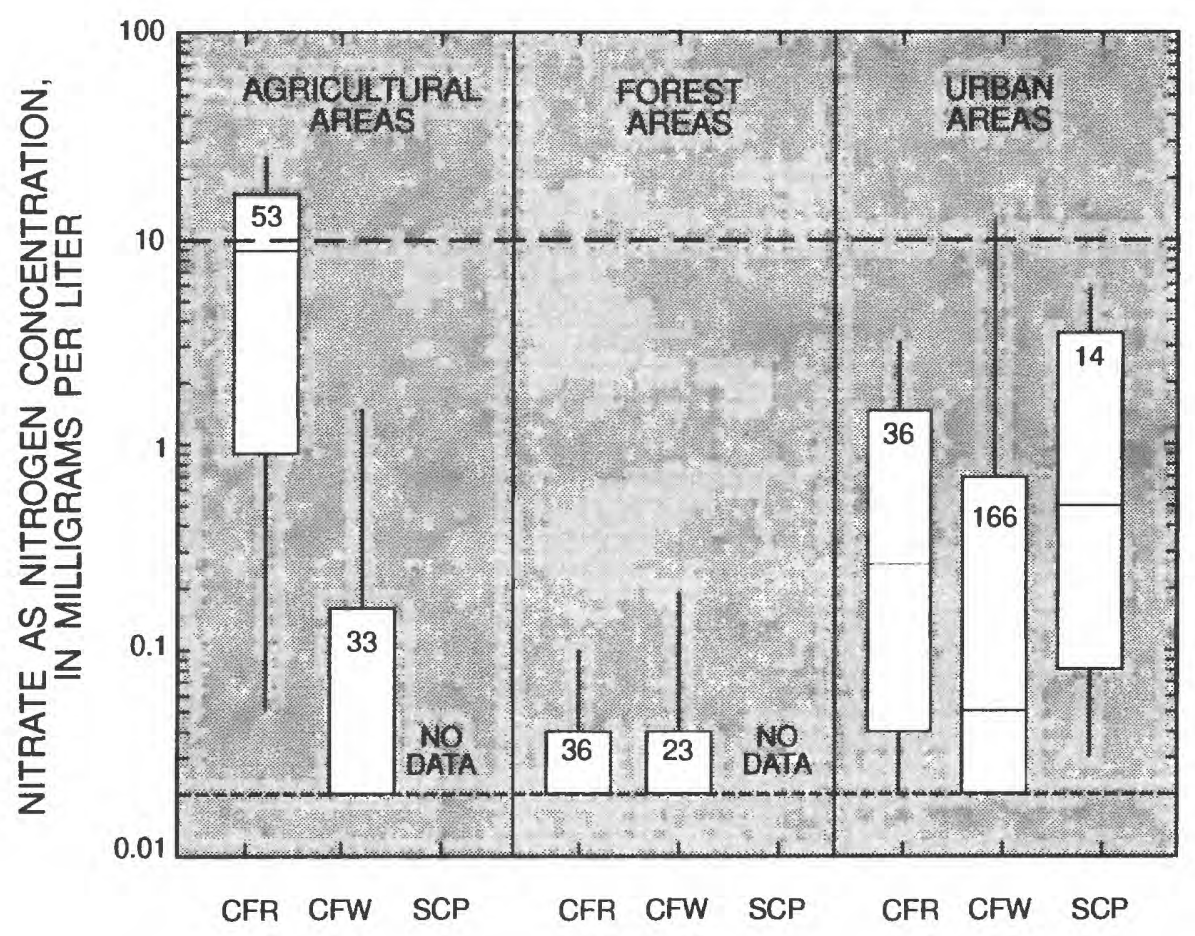

\section{EXPLANATION}

- MAXIMUM CONTAMINANT LEVEL - For drinking water, 10 milligrams per liter. Set by U.S. Environmental Protection Agency.

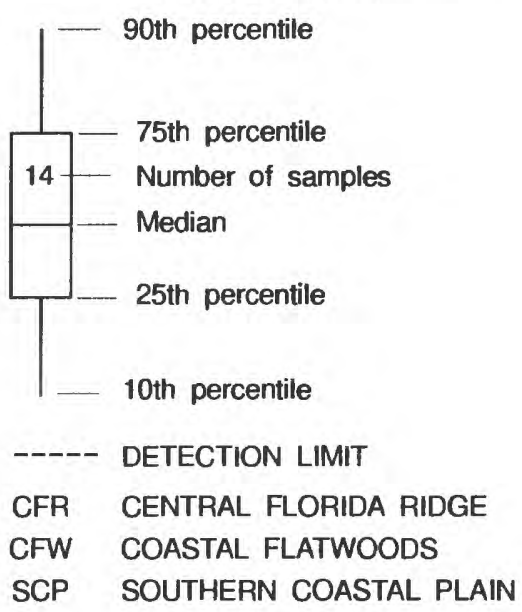

Figure 18. Nitrate concentrations in water from the surficial aquifer system in land-resource provinces for agricultural, forest, and urban areas in the Georgia-Florida Coastal Plain (U.S. Geological Survey data). 
Within categories of samples based on land use and confinement in the USGS data from the Upper Floridan aquifer, median nitrate concentrations in ground-water samples were low and ranged from 0.02 $\mathrm{mg} / \mathrm{L}$ to $0.40 \mathrm{mg} / \mathrm{L}$ (fig. 17). Because only the three major land uses are included in the categories, not all of the samples listed in table 6 are included in figure 17 and the graphs in the remainder of the report. The highest median concentrations of nitrate in ground water, $0.40 \mathrm{mg} / \mathrm{L}$ and $0.28 \mathrm{mg} / \mathrm{L}$, were from the unconfined Upper Floridan aquifer in agricultural and urban areas, respectively (fig. 17).

Within categories of land use and land resource provinces in the USGS data from the surficial aquifer system, the median nitrate concentrations in groundwater samples were highly variable and ranged from $0.02 \mathrm{mg} / \mathrm{L}$ to $9.0 \mathrm{mg} / \mathrm{L}$ (fig. 18). The lowest median nitrate concentrations were in agricultural areas in the Coastal Flatwoods and forest areas in the Central Florida Ridge and the Coastal Flatwoods. The highest median nitrate concentration was in samples from agricultural areas in the Central Florida Ridge (fig. 18). Results of the Wilcoxon rank-sum test on the samples in the agricultural areas of the Central Florida Ridge compared to agricultural areas in the Coastal Flatwoods indicated that the difference is significant at the 0.05 significance level ( $p$-value $<0.01$ ). The differences in the nitrate concentrations in the two agricultural areas may be related to agricultural practices and soil characteristics. Many of the samples from the Central Florida Ridge were collected from orchards, mostly citrus, and nurseries, whereas the samples from the Coastal Flatwoods are from row-crop agriculture. The soils on the Central Florida Ridge are extremely well drained, whereas the soils in the Coastal Flatwoods are moderately to well drained.

In the FDEP data, median nitrate concentrations were low, and few samples had concentrations greater than $10 \mathrm{mg} / \mathrm{L}$. The median nitrate concentrations for the 681 samples from the Upper Floridan aquifer was $0.01 \mathrm{mg} / \mathrm{L}$ (table 6). The median concentration of 139 samples collected from the surficial aquifer system was $0.01 \mathrm{mg} / \mathrm{L}$ (table 6). In the Upper Floridan aquifer, of the 681 samples in the FDEP data, only 5 samples (about 1 percent) from the Upper Floridan aquifer had nitrate concentrations greater than $10 \mathrm{mg} / \mathrm{L}$. In FDEP samples from the surficial aquifer system, only 3 samples ( 2 percent) from the surficial aquifer system had nitrate concentrations greater than $10 \mathrm{mg} / \mathrm{L}$ (fig. 16).
Except for the median nitrate concentration of $0.20 \mathrm{mg} / \mathrm{L}$ in agricultural areas in the unconfined Upper Floridan aquifer, median nitrate concentrations for FDEP data from the Upper Floridan aquifer did not exceed the detection limit of $0.05 \mathrm{mg} / \mathrm{L}$ (fig. 19). For the surficial aquifer system, several categories of land use and land resource provinces had less than 10 samples which precluded the construction of meaningful boxplots (fig. 20). Median nitrate concentrations in four categories from the surficial aquifer system were $0.05 \mathrm{mg} / \mathrm{L}$ (fig. 20).

In the GGS data, the median nitrate concentration was $0.7 \mathrm{mg} / \mathrm{L}$ (table 6) and few samples had concentrations greater than $10 \mathrm{mg} / \mathrm{L}$. Of the 680 samples, only 7 samples ( 1 percent) had nitrate concentrations greater than $10 \mathrm{mg} / \mathrm{L}$ (fig.16). Within five categories based on land resource provinces and land use, the median nitrate concentrations ranged from $0.1 \mathrm{mg} / \mathrm{L}$ in urban areas in the Southern Coastal Plain to $1.4 \mathrm{mg} / \mathrm{L}$ in agricultural areas in the Coastal Flatwoods (fig. 21).

Hydrogeology and land use have affected nitrate concentrations in the Georgia-Florida Coastal Plain as shown by the data from the three sources. Nitrate concentrations were highest in poorly confined aquifers, which include the unconfined and semiconfined Upper Floridan aquifer and the surficial aquifer system (figs 16-20). In the surficial aquifer system, nitrate concentrations were highest in agricultural areas. Many of the samples with nitrate greater than $10 \mathrm{mg} / \mathrm{L}$ in the USGS data were from the Central Florida Ridge in Polk County, which had nitrogen inputs greater than 10 tons $/ \mathrm{mi}^{2}$ (fig. 7). Also, 2 of the 3 samples from the surficial aquifer system with nitrate greater than $10 \mathrm{mg} / \mathrm{L}$ in the FDEP data were from Polk County. In the GGS data, 4 of the 7 samples with nitrate greater than $10 \mathrm{mg} / \mathrm{L}$ were located in agricultural areas in counties (Bulloch, Coffee, Cook, and Irwin) with nitrogen inputs greater than than 10 tons $/ \mathrm{mi}^{2}$ (fig. 7). Within the surficial aquifer system in agricultural areas, nitrate concentrations were highest in the Central Florida Ridge, which has soils that are excessively well-drained sand, and lowest in the Southern Coastal Plain, which has soils that are poorly to moderately drained sand and clayey sand (figs. 18, 20, and 21). In urban areas in the surficial aquifer system and unconfined and semiconfined Upper Floridan aquifer, high nitrate concentrations were mostly in samples from the USGS data that were collected in Leon and Pinellas Counties, Fla., near sites where treated sewage was discharged through land application. 


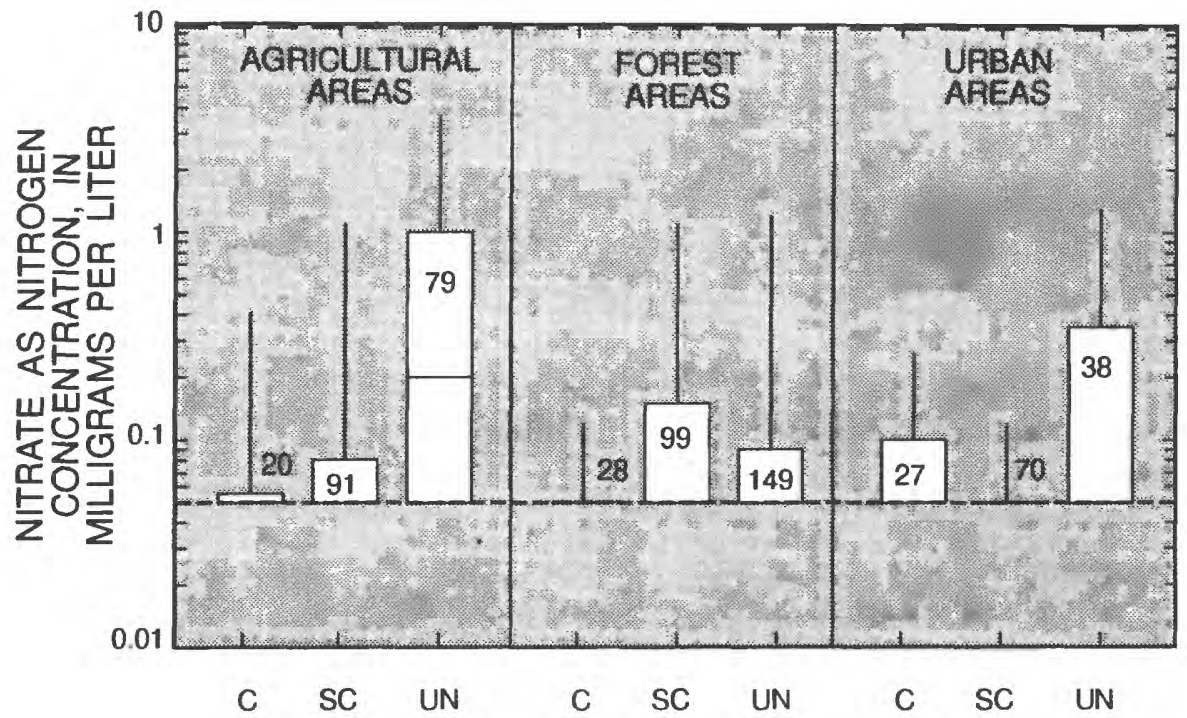

\section{EXPLANATION}

- MAXIMUM CONTAMINANT

LEVEL-For drinking water,

10 milligrams per liter. Set

by U.S. Environmental

Protection Agency.

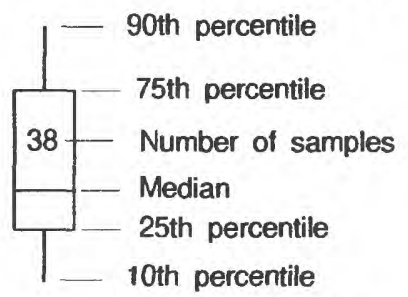

-..- DETECTION LIMIT

C CONFINED

SC SEMICONFINED

UN UNCONFINED

Figure 19. Nitrate concentrations in water from the Upper Floridan aquifer in confined, semiconfined, and unconfined areas for agricultural, forest, and urban areas in the Georgia-Florida Coastal Plain (Florida Department of Environmental Protection data).

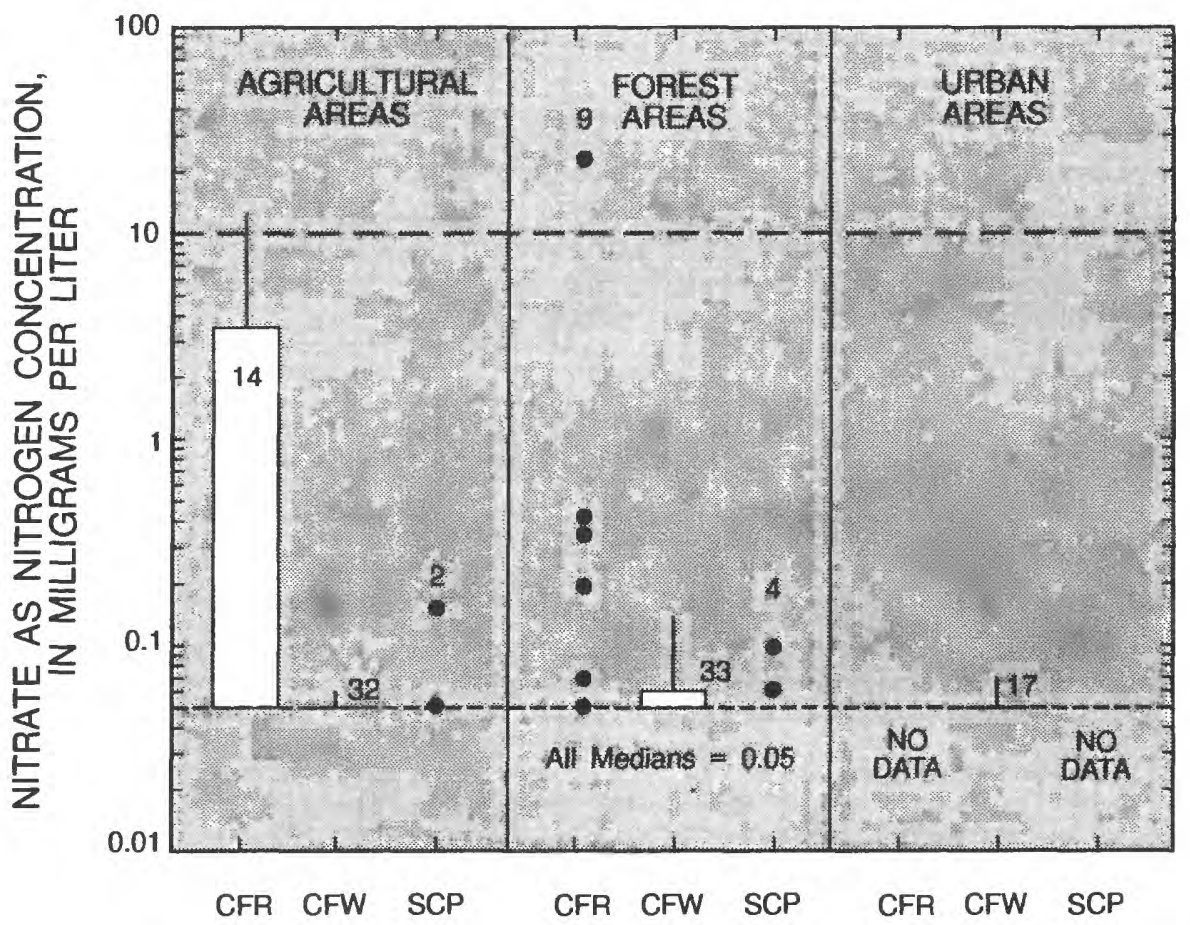

\section{EXPLANATION}

- - MAXIMUM CONTAMINANT LEVEL - For drinking water, 10 milligrams per liter. Set by U.S. Environmental Protection Agency.

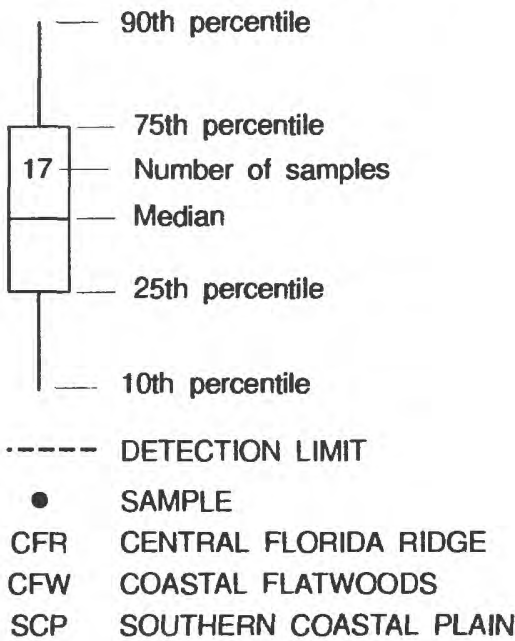

Figure 20. Nitrate concentrations in water from the surficial aquifer system in land-resource provinces for agricultural, forest, and urban areas in the Georgia-Florida Coastal Plain (Florida Department of Environmental Protection data). 


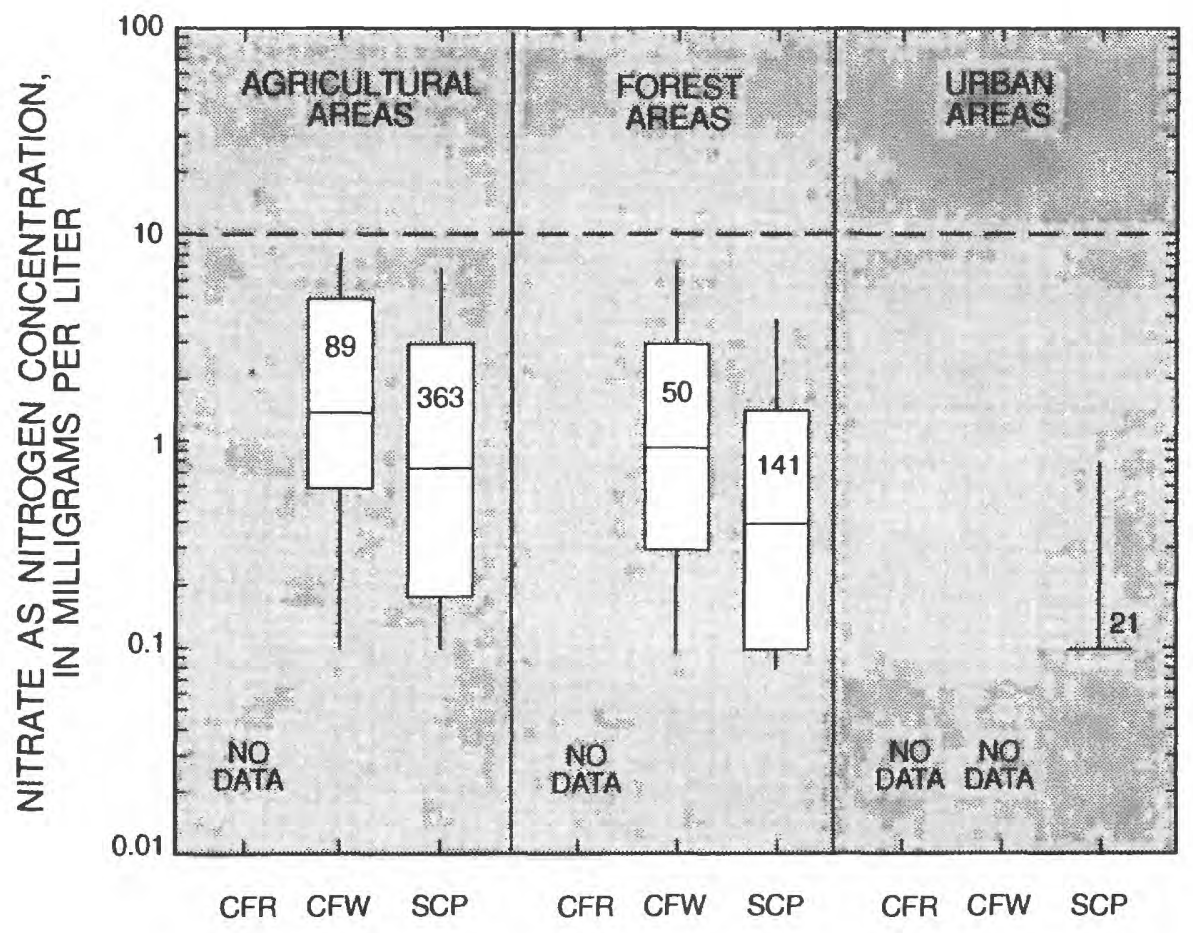

EXPLANATION

- MAXIMUM CONTAMINANT LEVEL-For drinking water, 10 milligrams per liter. Set by U.S. Environmental Protection Agency.

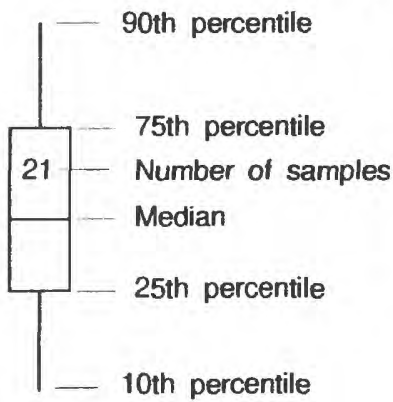

CFR CENTRAL FLORIDA RIDGE CFW COASTAL FLATWOODS SCP SOUTHERN COASTAL PLAIN

Figure 21. Nitrate concentrations in ground water in land resource provinces for agricultural, forest, and urban areas in the Georgia-Florida Coastal Plain (Georgia Geologic Survey data).

Sufficient data were available to determine trends in nitrate concentrations in ground-water from the unconfined Upper Floridan aquifer in central Florida. Nitrate concentrations were generally available in the USGS data within the time period 1972-91 for samples collected from 11 wells in Marion and Citrus Counties, Fla. (fig. 12). The wells were generally sampled twice annually. Six of the eleven wells are located in agricultural areas, 3 in forest areas, and 2 in urban areas and most well depths were less than $100 \mathrm{ft}$ (figs. 22-24). Concentrations of nitrate did not exceed $2.5 \mathrm{mg} / \mathrm{L}$ in any of the land-use areas. Significant trends in nitrate concentrations ( $p$-value $<0.05$ ) were indicated for the samples from each of the six wells in agricultural areas using the Mann-Kendall test for trend (fig. 22). The agricultural activities in this area are generally row-crop agriculture. No significant trends in nitrate concentration were indicated for samples from three wells in forest areas, although nitrate concentrations increased for a period of several years in samples from one well (fig. 23) located near the city of Ocala, Fla. (near a residential area and some sewage disposal ponds). Nitrate concentrations in samples from one of two wells in urban areas near Ocala, Fla., indicated a trend, whereas the other well indicated no trend (fig. 24). Differences in the two wells may be related to their locations, the well with samples showing a trend in nitrate concentrations was located less than 0.5 mile from several sewage disposal ponds. The other well was located near a highway.

\section{Ammonia}

Ammonia concentrations were generally low in ground-water samples from the Upper Floridan aquifer and the surficial aquifer system. Of 494 samples from the Upper Floridan aquifer in the USGS data, 455 samples ( 92 percent) had ammonia concentrations less than $1.0 \mathrm{mg} / \mathrm{L}$. Of 474 samples from the surficial aquifer system in the USGS data, 387 samples ( 82 percent) had ammonia concentrations less than $1.0 \mathrm{mg} / \mathrm{L}$. The median ammonia concentration in samples from the Upper Floridan aquifer was $0.10 \mathrm{mg} / \mathrm{L}$ (table 6). The median ammonia concentration in the samples from the surficial aquifer system was $0.15 \mathrm{mg} / \mathrm{L}$ (table 6). 

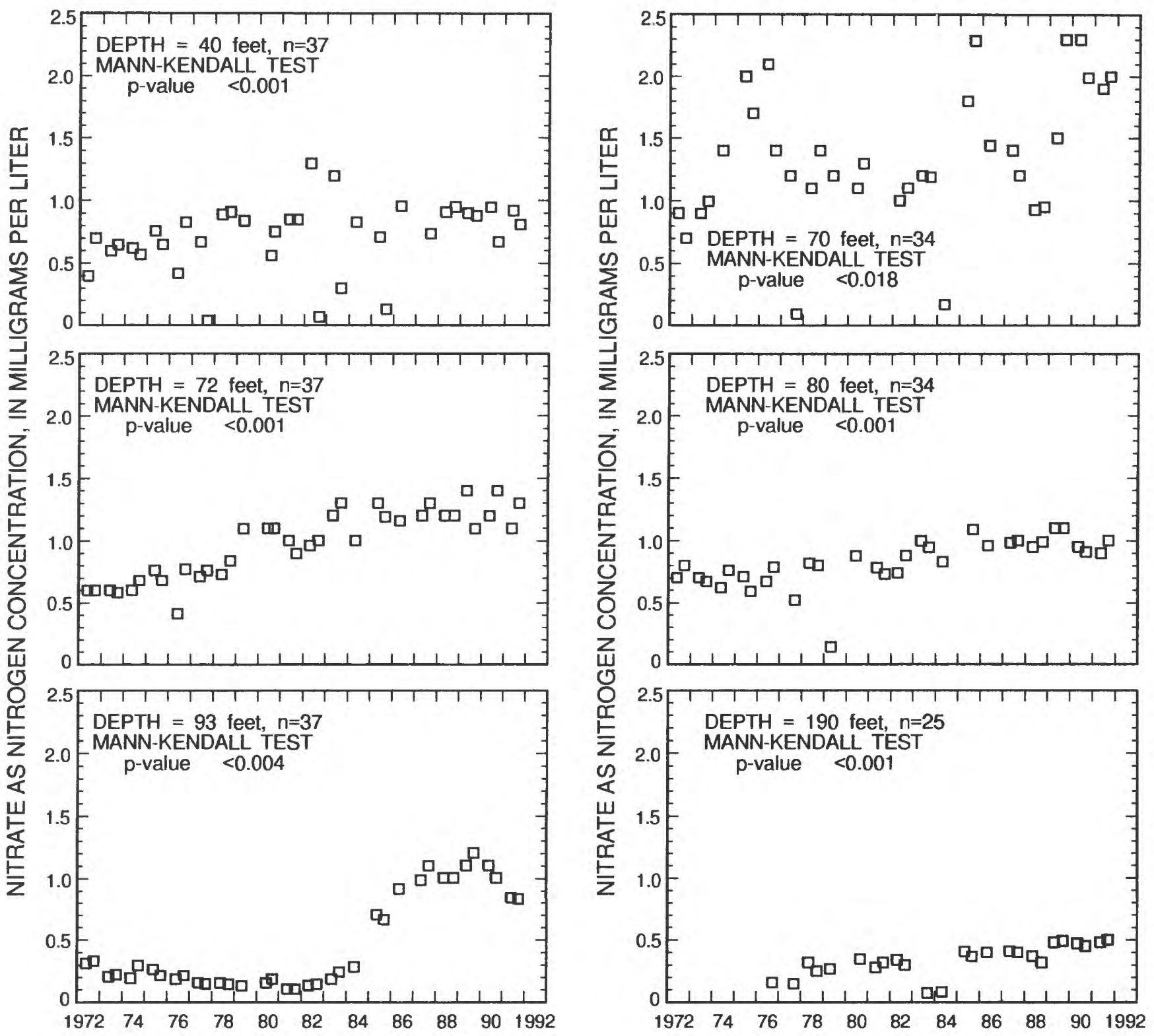

Figure 22. Nitrate concentrations for the period 1972-91, in ground water from the unconfined Upper Floridan aquifer in agricultural areas in central Florida in the Georgia-Florida Coastal Plain (U.S. Geological Survey data). 

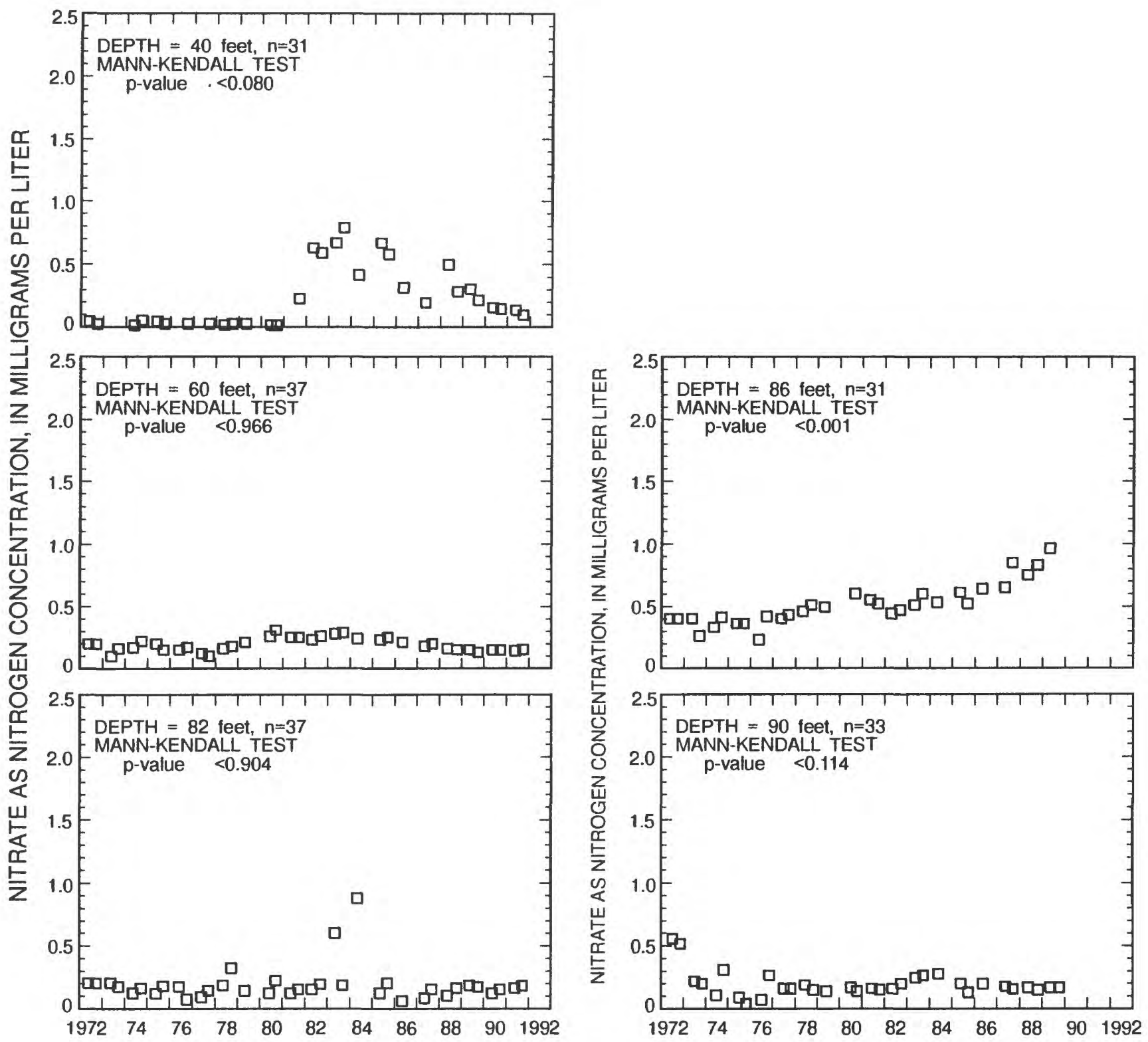

Figure 23. Nitrate concentrations for the period 1972-91, in ground water from the unconfined and semiconfined Upper Floridan aquifer in forest areas in central Florida in the GeorgiaFlorida Coastal Plain (U.S. Geological Survey data).
Figure 24. Nitrate concentrations for the period 1972-89, in ground water from the unconfined Upper

Floridan aquifer in urban areas in central Florida in the Georgia-Florida Coastal Plain (U.S. Geological Survey data). 

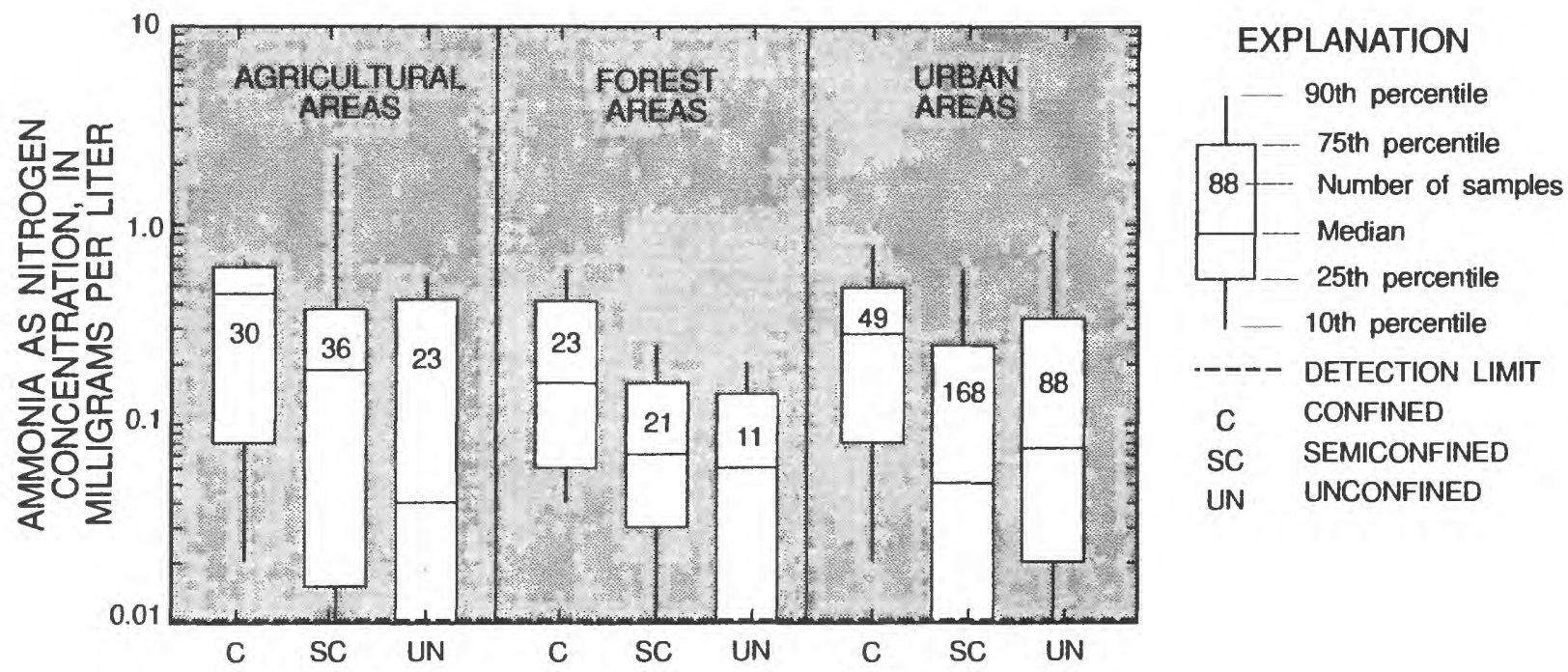

Figure 25. Ammonia concentrations in water from the Upper Floridan aquifer in confined, semiconfined, and unconfined areas for agricultural, forest, and urban areas in the Georgia-Florida Coastal Plain (U.S. Geological Survey).
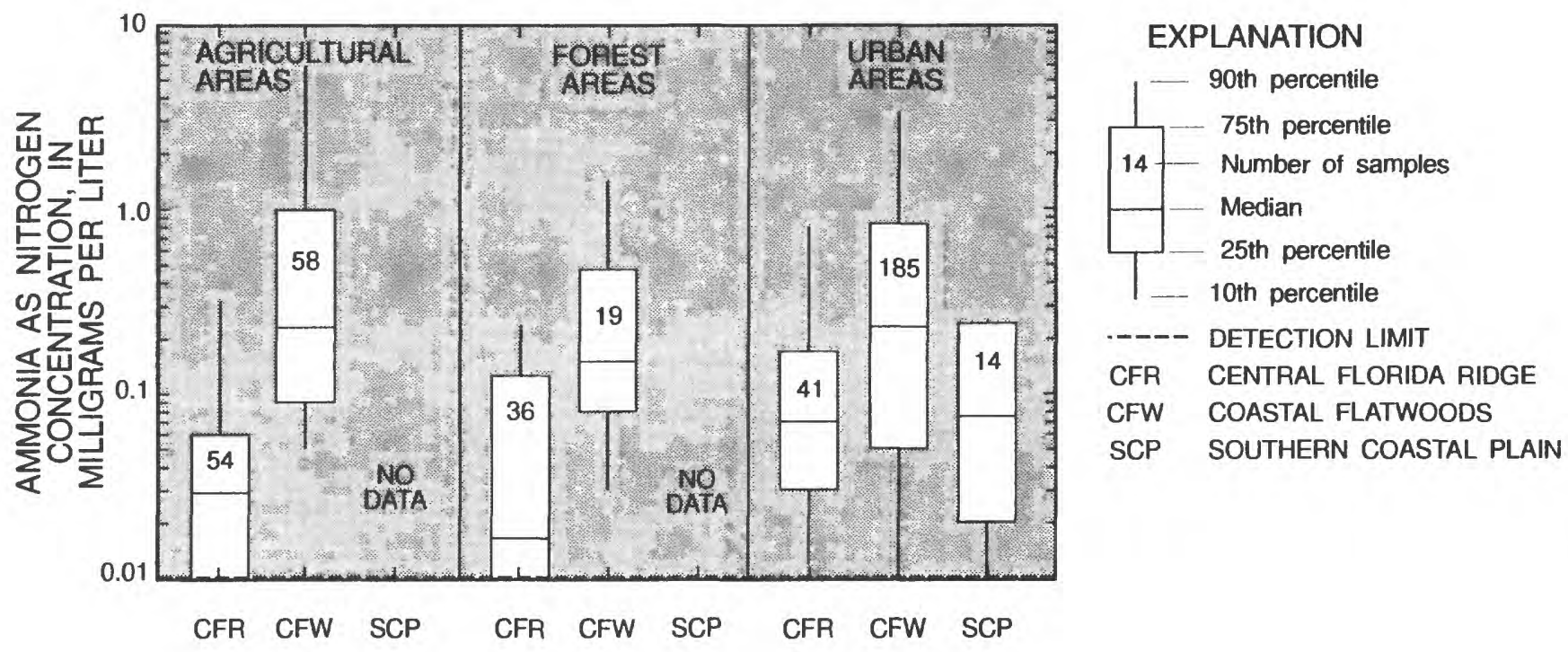

Figure 26. Ammonia concentrations in water from the surficial aquifer system in land resource provinces for agricultural, forest, and urban areas in the Georgia-Florida Coastal Plain (U.S. Geological Survey data). 
Median concentrations of ammonia in water from the Upper Floridan aquifer were less than $0.5 \mathrm{mg} / \mathrm{L}$ in categories of land use and degree of confinement (fig. 25). The highest median ammonia concentrations, $0.45 \mathrm{mg} / \mathrm{L}$ and $0.28 \mathrm{mg} / \mathrm{L}$, were in confined parts of the aquifer in agricultural and urban areas, respectively. In contrast, the median concentrations of nitrate were lowest in ground-water samples from confined parts of the aquifer (fig. 17). Similar results were noted by Sprinkle (1989) in his examination of nitrogen species in 390 ground-water samples in the Upper Floridan aquifer. Sprinkle (1989) indicated that oxidizing conditions are present in unconfined, recharge parts of the Upper Floridan aquifer and nitrate concentrations are elevated, whereas reducing conditions are present in confined areas and ammonia concentrations are elevated (relative to unconfined areas).

Median concentrations of ammonia in water from the surficial aquifer system were less than 0.30 $\mathrm{mg} / \mathrm{L}$ in the categories based on land use and land resource provinces (fig. 26). Median concentrations of ammonia were slightly higher in ground water samples from agricultural and urban areas in the Coastal Flatwoods than in the other categories of samples (fig. 26).

In the FDEP data, ammonia concentrations were only available for 32 ground-water samples. The median ammonia concentrations for 9 samples from the Upper Floridan aquifer was $0.28 \mathrm{mg} / \mathrm{L}$ and the median for 23 samples from the surficial aquifer system was 0.27 $\mathrm{mg} / \mathrm{L}$. Ammonia data from FDEP data were not available in sufficient numbers to be analyzed by categories.

\section{Total Nitrogen}

Total nitrogen concentrations in ground-water samples from the Upper Floridan aquifer and the surficial aquifer system were generally low. Total nitrogen were only available from the USGS data. Of the 347 samples from the Upper Floridan aquifer, 214 samples (62 percent) had total nitrogen concentrations less than $1.0 \mathrm{mg} / \mathrm{L}$. Of the 290 samples from the surficial aquifer system, 101 ( 35 percent) had total nitrogen concentrations less than $1.0 \mathrm{mg} / \mathrm{L}$. The median concentration for total nitrogen was $0.69 \mathrm{mg} / \mathrm{L}$ in the Upper Floridan aquifer and $1.61 \mathrm{mg} / \mathrm{L}$ in the surficial aquifer system (table 6). Median concentrations of total nitrogen are slightly higher in both aquifers than either nitrate or ammonia concentrations because total nitrogen concentrations are the sum of nitrate, ammonia, and organic nitrogen concentrations.
Median concentrations of total nitrogen in categories of samples from the Upper Floridan aquifer ranged from $0.3 \mathrm{mg} / \mathrm{L}$ to $1.4 \mathrm{mg} / \mathrm{L}$, with the highest median concentration of total nitrogen in the unconfined parts of the aquifer in urban areas (fig. 27). Samples from the surficial aquifer system had slightly higher concentrations than samples from the Upper Floridan aquifer. Median concentrations of total nitrogen in the surficial aquifer system ranged from 0.53 $\mathrm{mg} / \mathrm{L}$ in samples from forest areas in the Coastal Flatwoods, to $11.3 \mathrm{mg} / \mathrm{L}$ in samples from agricultural areas in the Central Florida Ridge (fig. 28). Samples from this same category (agricultural areas in the Central Florida Ridge) also had the highest median nitrate concentration $(9.0 \mathrm{mg} / \mathrm{L}$ ) (fig. 18), indicating that most of the total nitrogen is nitrate.

\section{Orthophosphate}

Orthophosphate as phosphorus concentrations in ground-water samples from the Upper Floridan aquifer and the surficial aquifer system were extremely low. Most concentrations were less than or equal to the analytical detection limit of $0.01 \mathrm{mg} / \mathrm{L}$. Data for orthophosphate were available from USGS and FDEP data. Of 341 samples from the Upper Floridan aquifer in the USGS data, 334 samples ( 98 percent) had concentrations less than $1.0 \mathrm{mg} / \mathrm{L}$. Of 181 samples from the surficial aquifer system in the USGS data, 167 samples (92 percent) had concentrations less than $1.0 \mathrm{mg} / \mathrm{L}$. Median concentrations of orthophosphate in the USGS data for all samples in the Upper Floridan aquifer and the surficial aquifer system were $0.02 \mathrm{mg} / \mathrm{L}$ and $0.03 \mathrm{mg} / \mathrm{L}$, respectively (table 6). In categories of samples from the Upper Floridan aquifer, concentration of orthophosphate showed little variation; the median concentrations were equal to or less than $0.03 \mathrm{mg} / \mathrm{L}$ (fig. 29). Concentrations of orthophosphate in categories of samples from the surficial aquifer system also showed little variation; median concentrations in agricultural, forest, and urban areas only ranged from 0.02 to $0.17 \mathrm{mg} / \mathrm{L}$ (fig. 30).

In the FDEP data, all samples from the Upper Floridan aquifer and the surficial aquifer system had orthophosphate concentrations less than $1.0 \mathrm{mg} / \mathrm{L}$. Median concentrations of orthophosphate in the FDEP data in the Upper Floridan aquifer (113 samples) and the surficial aquifer system ( 40 samples) were $0.09 \mathrm{mg} / \mathrm{L}$ and $0.07 \mathrm{mg} / \mathrm{L}$, respectively (table 6). The 


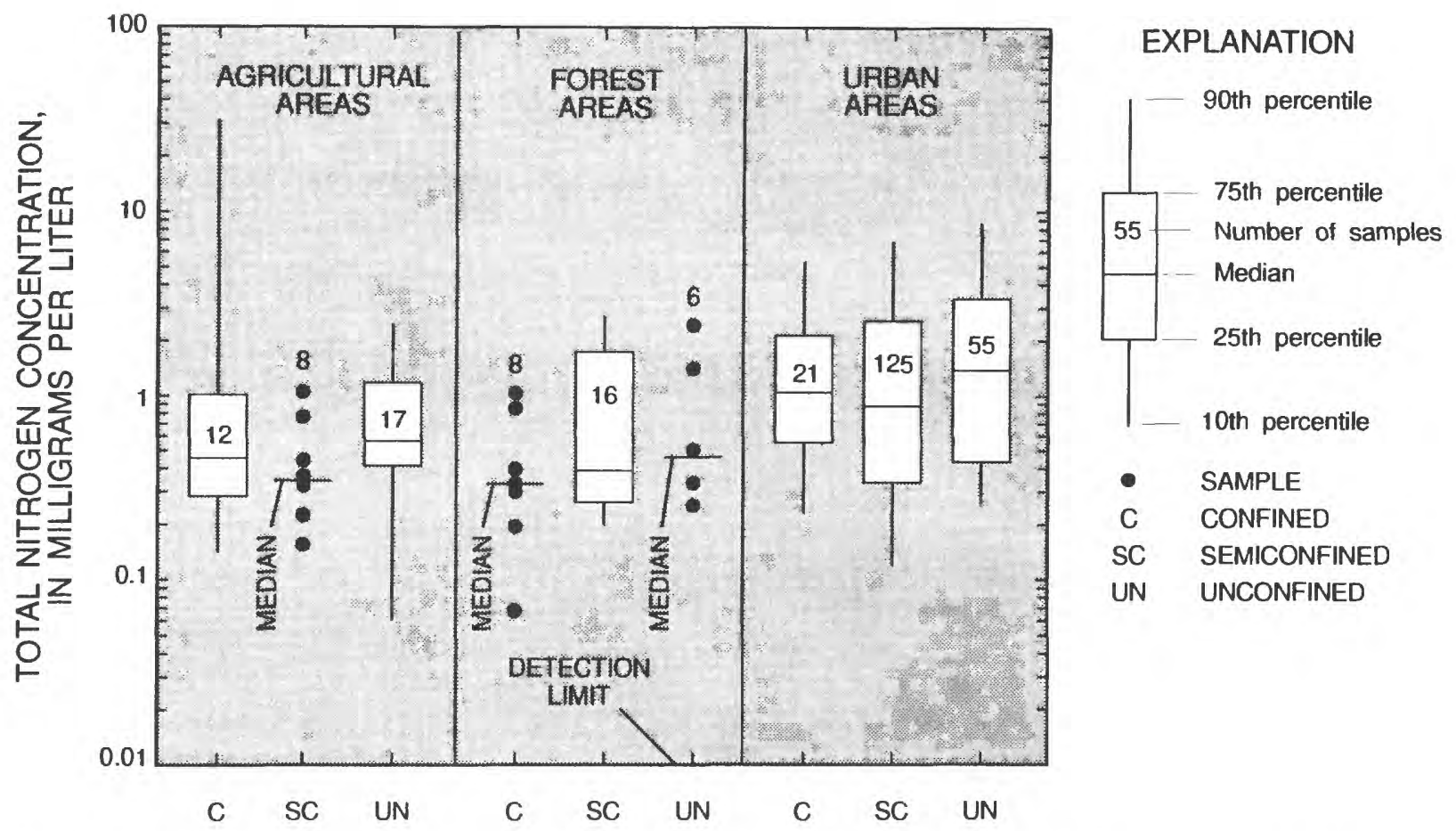

Figure 27. Total nitrogen concentrations in water from the Upper Floridan aquifer in confined, semiconfined, and unconfined areas for agricultural, forest, and urban areas in the Georgia-Florida Coastal Plain (U.S. Geological Survey data).

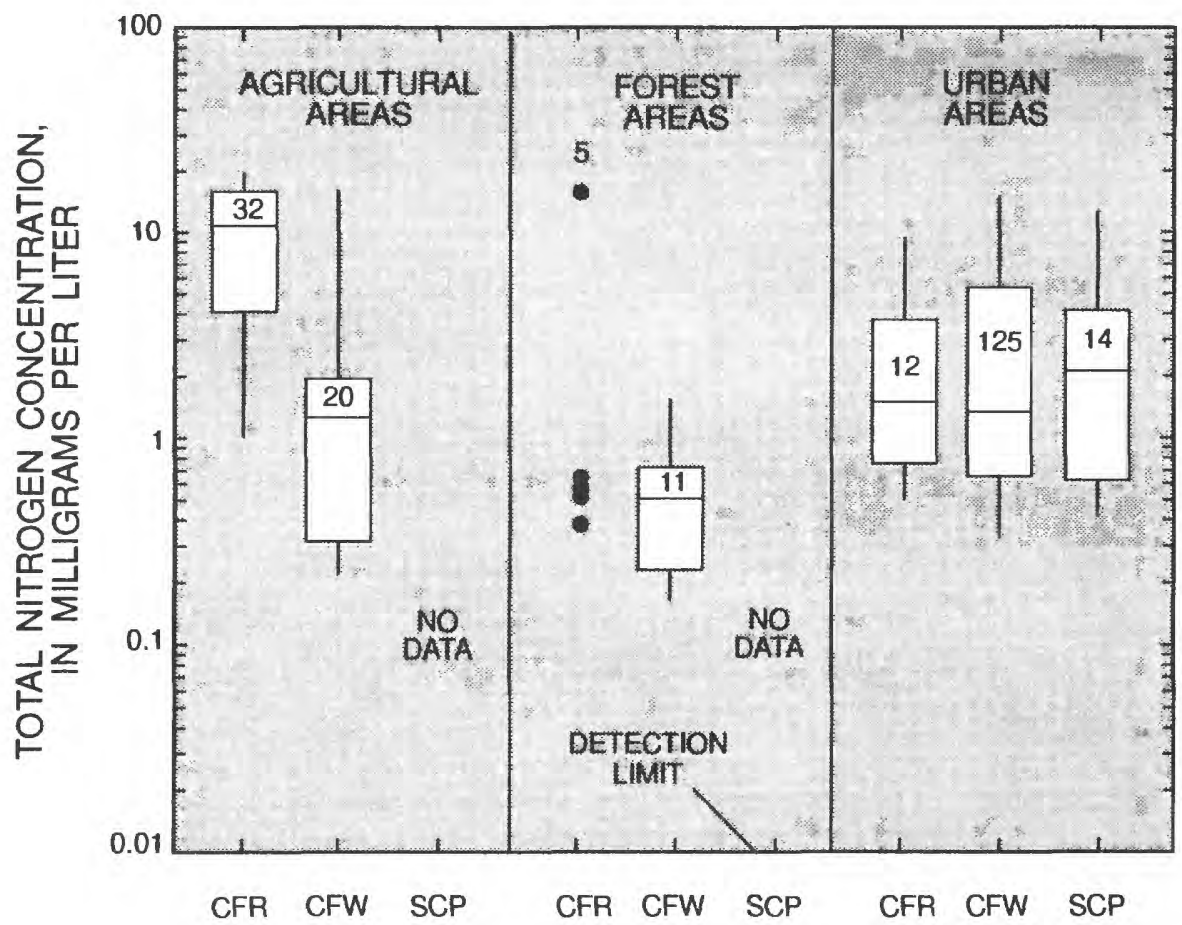

\section{EXPLANATION}

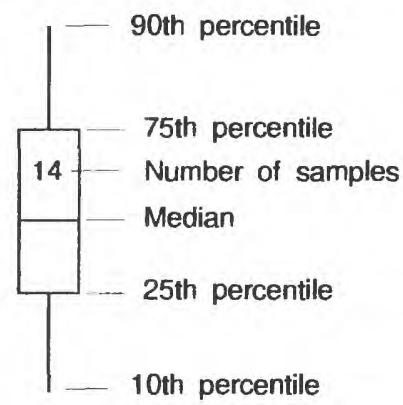

$\begin{array}{cl}- & \text { SAMPLE } \\ \text { CFR } & \text { CENTRAL FLORIDA RIDGE } \\ \text { CFW } & \text { COASTAL FLATWOODS }\end{array}$

SCP SOUTHERN COASTAL PLAIN

Figure 28. Total nitrogen concentrations in water from the surficial aquifer system in land resource provinces for agricultural, forest, and urban areas in the Georgia-Florida Coastal Plain (U.S. Geological Survey data). 

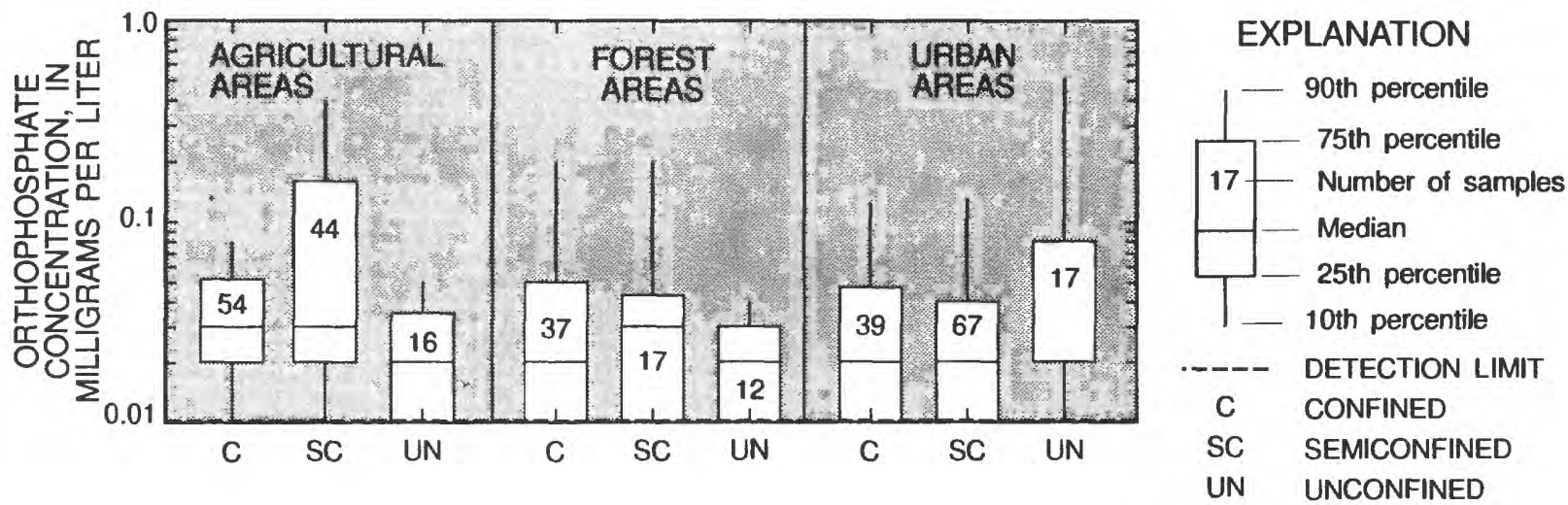

Figure 29. Orthosphosphate concentrations in water from the Upper Floridan aquifer in confined, semiconfined, and unconfined areas for agricultural, forest, and urban areas in the Georgia-Florida Coastal Plain (U.S. Geological Survey data).

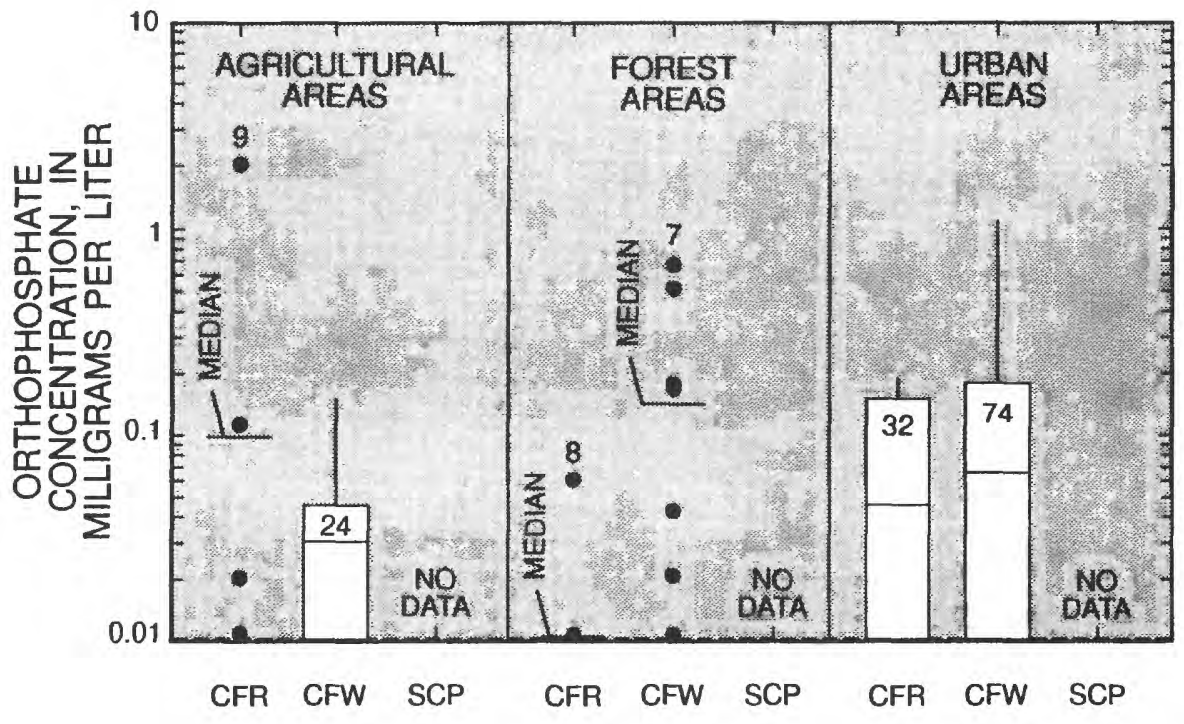

EXPLANATION

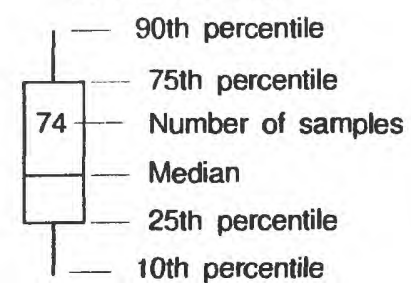

- SAMPLE

----- DETECTION LIMIT

CFR CENTRAL FLORIDA RIDGE

CFW COASTAL FLATWOODS

SCP SOUTHERN COASTAL PLAIN

Figure 30. Orthosphosphate concentrations in water from the surficial aquifer system in land resource provinces for agricultural, forest, and urban areas in the Georgia-Florida Coastal Plain (U.S. Geological Survey). 

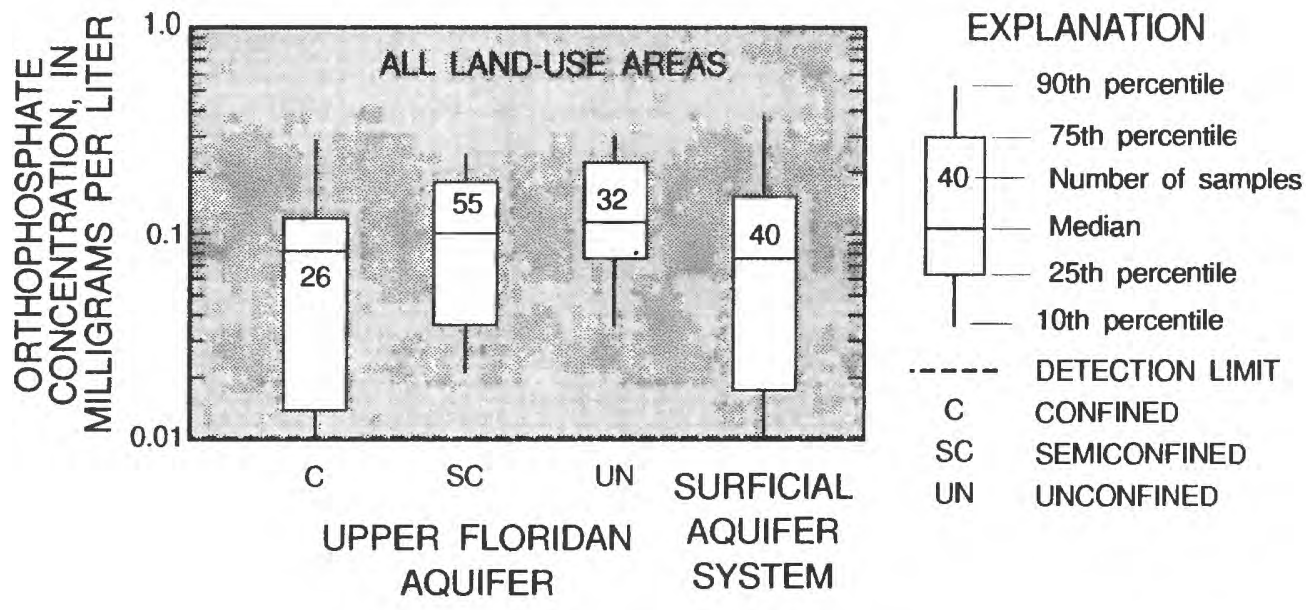

Figure 31. Orthophosphate concentrations in water from the Upper Floridan aquifer in confined, semiconfined, and unconfined areas and from the surficial aquifer system in the Georgia-Florida Coastal Plain (Florida Department of Environmental Protection data).

highest median concentration in the Upper Floridan aquifer categories by confinement was $0.11 \mathrm{mg} / \mathrm{L}$ (fig. 31). Insufficient data were available for orthophosphate in the FDEP data to compare concentrations by land use or land resource provinces for the samples from the surficial aquifer system categories.

\section{Total Phosphorus}

Total phosphorus concentrations in ground-water samples from the Upper Floridan aquifer and the surficial aquifer system were generally low in the USGS data. Of 413 samples from the Upper Floridan aquifer, 382 samples ( 92 percent) had phosphorus concentrations less than $1.0 \mathrm{mg} / \mathrm{L}$. Of 349 samples from the surficial aquifer system, 289 samples ( 83 percent) had phosphorus concentrations less than $1.0 \mathrm{mg} / \mathrm{L}$. Median concentrations of total phosphorus in the USGS data from the Upper Floridan aquifer and the surficial aquifer system were 0.06 and $0.21 \mathrm{mg} / \mathrm{L}$, respectively (table 6). In categories of confinement and land use in the Upper Floridan aquifer, the median concentrations of total phosphorus ranged from $0.04 \mathrm{mg} / \mathrm{L}$ to $0.12 \mathrm{mg} / \mathrm{L}$ (fig. 32), with the highest median concentration in the confined Upper Floridan aquifer in urban areas. In categories of land resource provinces and land use in the surficial aquifer system, samples in forest areas in the Central Florida Ridge had the highest median concentration of total phosphorus of $0.34 \mathrm{mg} / \mathrm{L}$ (fig. 33).

Nearly all ground-water samples in the FDEP data had total phosphorus concentrations less than $1.0 \mathrm{mg} / \mathrm{L}$ and many samples had concentrations equal to or less than the detection limit of $0.1 \mathrm{mg} / \mathrm{L}$. Of 373 samples from the Upper Floridan aquifer, 372 samples (greater than 99 percent) had phosphorus concentrations less than $0.1 \mathrm{mg} / \mathrm{L}$. Of 26 samples from the surficial aquifer system, 25 (96 percent) had phosphorus concentrations less than $1.0 \mathrm{mg} / \mathrm{L}$. Because few samples had total phosphorus concentrations greater than the detection limits boxplots were not prepared for the Upper Floridan aquifer or the surficial aquifer system. In the Upper Floridan aquifer 338 out of 373 samples ( 91 percent) had concentrations equal to or less than the detection limit of $0.10 \mathrm{mg} / \mathrm{L}$ and in the surficial aquifer system 16 out 26 samples ( 62 percent) had concentrations equal to or less than the detection limit. 


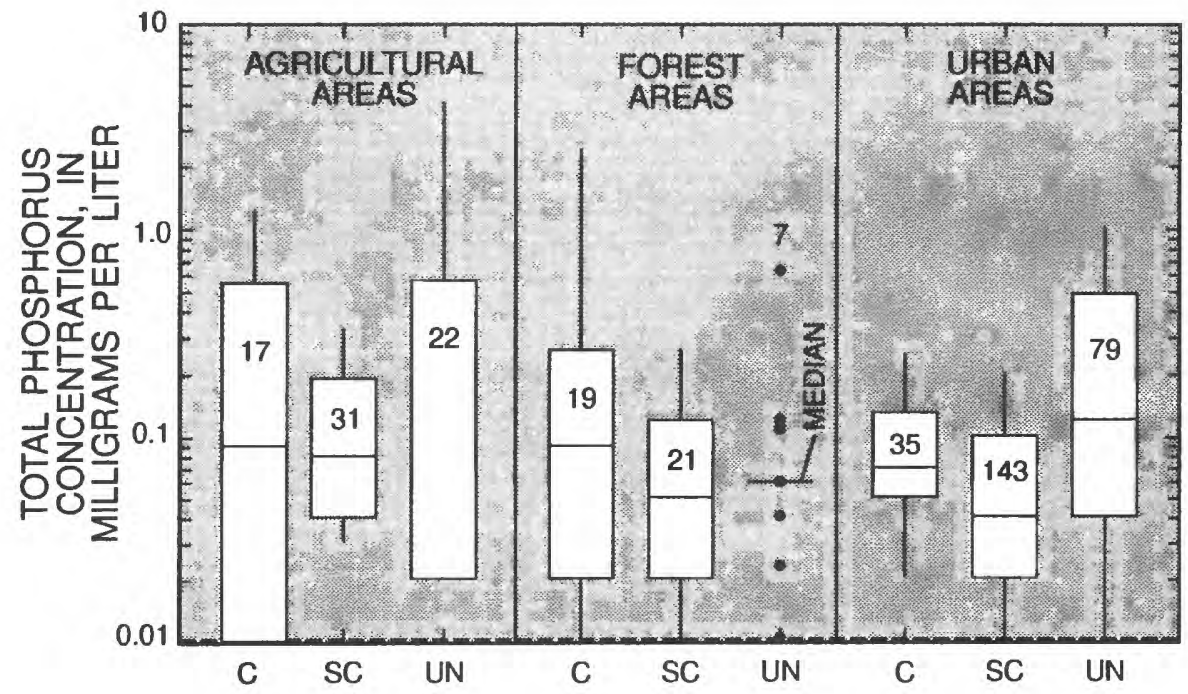

\section{EXPLANATION}

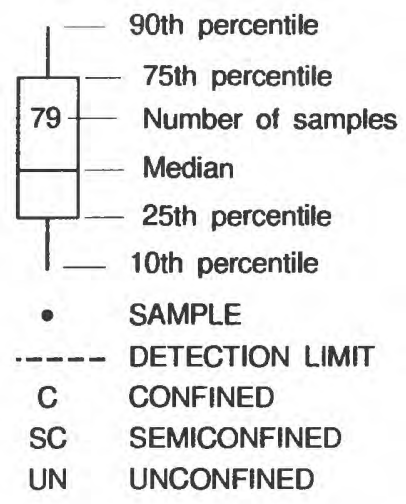

Figure 32. Total phosphorus concentrations in water from the Upper Floridan aquifer in confined, semiconfined, and unconfined areas for agricultural, forest, and urban areas in the Georgia-Florida Coastal Plain (U.S. Geological Survey data).

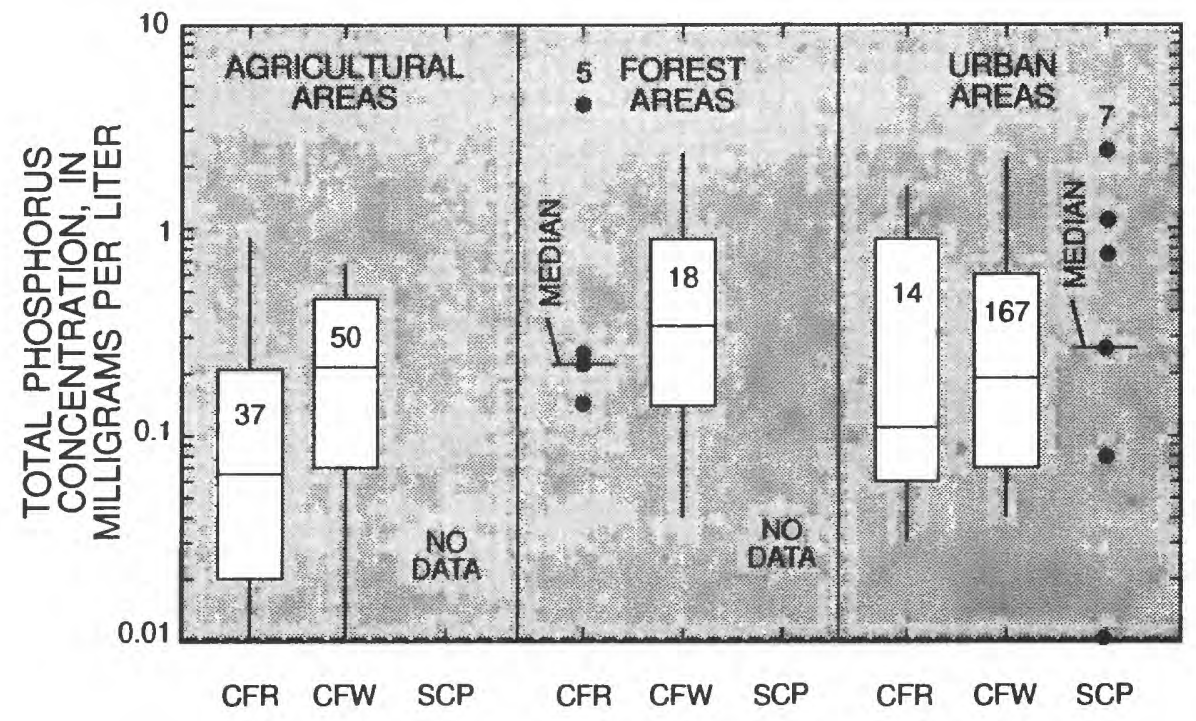

\section{EXPLANATION}

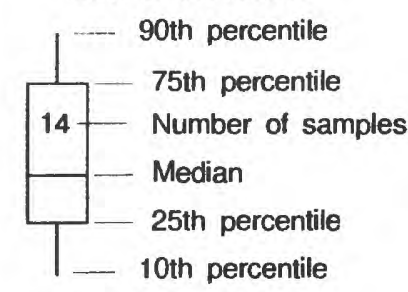

SAMPLE

DETECTION LIMIT

CFR CENTRAL FLORIDA RIDGE

CFW COASTAL FLATWOODS

SCP SOUTHERN COASTAL PLAIN

Figure 33. Total phosphorus concentrations in water from the surficial aquifer system in land resource provinces for agricultural, forest, and urban areas in the Georgia-Florida Coastal Plain (U.S. Geological Survey data). 


\section{SUMMARY}

The Georgia-Florida Coastal Plain study area is an area of nearly 62,000 square miles located on the southeastern coast of the United States. The population of the study area is approximately 9.3 million. Major cities located within the study area include Athens, Macon, Savannah, Valdosta, Warner Robins, and parts of metropolitan Atlanta in Georgia, and Clearwater, Daytona Beach, Gainesville, Jacksonville, Lakeland, Melbourne, Orlando, St. Petersburg, Tallahassee, and Tampa in Florida. Approximately 48 percent of the area of the study area is in forest land use and 28 percent is in agricultural land use. Land resource provinces have been designated based on generalized soil classifications. The Central Florida Ridge, Coastal Flatwoods, and Southern Coastal Plain are the major land resource provinces in the study area.

The primary source of drinking water in the study area is ground water from the Upper Floridan aquifer. In 1990, more than 90 percent of the ground water withdrawn in the study area was withdrawn from this aquifer. The highly productive Upper Floridan aquifer is the uppermost unit of the Floridan aquifer system and is composed of a sequence of carbonate rocks that includes aquifer units of high permeability and confining units of low permeability. The rocks that constitute this aquifer system reach a thickness of more than 3,000 feet along parts of the southern boundary of the study area. The Upper Floridan aquifer is considered confined where the thickness of overlying confining units are greater than 100 feet, semiconfined where the confining units are less than 100 feet thick and may be breached, and unconfined where the confining units are virtually absent and the Upper Floridan aquifer is at or near land surface. The surficial aquifer system, which overlies the Upper Floridan aquifer in most areas, is also used for drinking water supply mostly for domestic use.

Nutrient (nitrogen and phosphorus species) concentrations data for ground water were available from three sources: the U.S. Geological Survey (USGS) National Water Information System; the Florida Department of Environmental Protection (FDEP) Ground Water-Quality Monitoring Network; and Georgia Geologic Survey (GGS) Coastal Plain Nitrate Survey. Nitrate concentrations were low in groundwater samples from the surficial aquifer system and Upper Floridan aquifer from the three data sources. In the USGS data, 65 percent of ground-water samples from the Upper Floridan aquifer and the surficial aquifer system had nitrate (as nitrogen) concentrations less than 0.2 milligrams per liter $(\mathrm{mg} / \mathrm{L})$. In ground-water samples from the Upper Floridan aquifer and the surficial aquifer system, 3 percent and 12 percent, respectively, had nitrate concentrations greater than $10 \mathrm{mg} / \mathrm{L}$. More samples in the FDEP data had low nitrate concentrations; 79 percent of ground-water samples from the Upper Floridan aquifer and 90 percent of groundwater samples from the surficial aquifer system had concentrations less than $0.2 \mathrm{mg} / \mathrm{L}$. In the Upper Floridan aquifer and the surficial aquifer system, less than 1 percent and 2 percent of samples, respectively, had nitrate concentrations greater than $10 \mathrm{mg} / \mathrm{L}$. In ground-water samples from the GGS data, nitrate concentrations were slightly higher; only 28 percent of samples had nitrate concentrations less than $0.2 \mathrm{mg} / \mathrm{L}$. Only 5 percent of samples had nitrate concentrations greater than $10 \mathrm{mg} / \mathrm{L}$.

Concentrations of nitrogen and phosphorus species in ground-water samples were analyzed by grouping the data into categories based on land use, hydrogeology (aquifer and confinement of the Upper Floridan aquifer), and land resource provinces (for the surficial aquifer system only). The USGS data contained more samples collected in urban areas (46 percent), including some contamination sites, than the FDEP data (20 percent of samples from urban areas), which were collected to determine background ground-water quality, and the GGS data (4 percent of samples from urban areas), which were collected from domestic wells. Nitrate concentrations from all three data sources were generally low, except in unconfined aquifers in some land-use areas:

- In the USGS samples from the Upper Floridan aquifer, the highest median nitrate concentration was $0.4 \mathrm{mg} / \mathrm{L}$ in the unconfined aquifer in agricultural areas;

- In the USGS samples from the surficial aquifer system, the highest median nitrate concentration was $9.0 \mathrm{mg} / \mathrm{L}$ in agricultural areas in the Central Florida Ridge;

- In the FDEP samples from the Upper Floridan aquifer, the highest median nitrate concentration was $0.2 \mathrm{mg} / \mathrm{L}$ in the unconfined aquifer in agricultural areas;

- In the FDEP samples from the surficial aquifer system, the median nitrate concentrations in the surficial aquifer system in all categories were near the analytical detection limit of $0.05 \mathrm{mg} / \mathrm{L}$; 
- In the GGS samples, the highest median nitrate concentration was $1.4 \mathrm{mg} / \mathrm{L}$ in samples from agricultural areas in the Coastal Flatwoods.

Ammonia and total nitrogen concentrations, which were generally only available in the USGS data, were generally low in ground-water samples:

- In samples from the Upper Floridan aquifer, median concentrations of ammonia in all categories were less than $0.5 \mathrm{mg} / \mathrm{L}$;

- In samples from the surficial aquifer system, median concentrations of ammonia in all categories were less than $0.3 \mathrm{mg} / \mathrm{L}$;

- In samples from the Upper Floridan aquifer, the highest median concentration of total nitrogen was $1.4 \mathrm{mg} / \mathrm{L}$ in the unconfined aquifer in urban areas;

- In samples from the surficial aquifer system, the highest median concentration of total nitrogen was $11.3 \mathrm{mg} / \mathrm{L}$ in agricultural areas in the Central Florida Ridge.

Orthophosphate phosphorus and total phosphorus concentrations in the USGS and FDEP data were generally low in ground-water samples:

- In the USGS sampes from the Upper Floridan aquifer and the surficial aquifer system, the median orthophosphate phosphorus concentrations in all categories were less than or equal to $0.04 \mathrm{mg} / \mathrm{L}$;

- In the FDEP samples from the Upper Floridan aquifer and the surficial aquifer system, median concentrations of orthophosphate phosphorus in the FDEP data in four categories were less than or equal to $0.11 \mathrm{mg} / \mathrm{L}$;

- In the USGS samples form the Upper Floridan aquifer, the highest median concentration of total phosphorus was $0.43 \mathrm{mg} / \mathrm{L}$ in the confined Upper Floridan aquifer in agricultural areas:

- In the USGS samples from the surficial aquifer system, the highest median concentration of total phosphoruswas $8.0 \mathrm{mg} / \mathrm{L}$ in agricultural areas in the Central Florida Ridge;

- In the FDEP samples, primarily from the Upper Floridan aquifer, median concentrations of total phosphorus were all $0.10 \mathrm{mg} / \mathrm{L}$.

\section{REFERENCES}

Akioka, L.M., 1992, Georgia Statistical Abstract, 1992-93: Athens, The University of Georgia College of Business Administration, $535 \mathrm{p}$.

Anderson, J.R., Hardy, E.E., Roach, J.T., and Witmer, R.E., 1976, A land use and land cover classification system for use with remote sensor data: U.S. Geological Survey Professional Paper 964, 28 p.
Berndt, M.P., 1990, Sources and distribution of nitrate in ground water at a farmed field irrigated with sewage treatment-plant effluent, Tallahassee, Florida: U.S. Geological Survey Water-Resources Investigations Report 90-4006, $33 \mathrm{p}$.

Bradley, J. T., 1972, Climates of the states; Florida: Asheville, N.C., U.S. Department of Commerce, National Oceanic and Atmospheric Administration, Climatology of the United States no. 60-8, $31 \mathrm{p}$.

Bradner, L.A., 1991, Water quality in the Upper Floridan aquifer in the vicinity of drainage wells, Orlando, Florida: U.S. Geological Survey Water-Resources Investigations Report 90-4175, 57p.

Bush, P.W., and Johnston, R.H., 1988, Ground-water hydraulics, regional flow, and ground-water development of the Floridan aquifer system in Florida and in parts of Georgia, South Carolina, and Alabama: U.S. Geological Survey Professional Paper 1403-C, 80 p.

Caldwcll, R.E., and Johnson, R.W., 1982, General soil map, Florida: U.S. Department of Agriculture Soil Conservation Service, 1 sheet, scale 1:500,000.

Clarke, J.S., Brooks, R., and Faye, R.E., 1985, Hydrogeology of the Dublin and Midville aquifer systems of east-central Georgia: Georgia Geologic Survey Information Circular 74, $62 \mathrm{p}$.

Clarke, J.S., and Pierce, R.R., 1985, Georgia ground-water resources, in National Water Summary 1984-Hydrologic events, selected water-quality trends, and ground-water resources: U.S. Geological Survey Water-Supply Paper 2275, p. 179-184.

Fernald, E.A., and Patton, D.J., 1984, Water resources atlas of Florida: Tallahassee, Florida State University, 291 p.

Fernald, E.A., and Purdum, E.D., 1992, editors, Atlas of Florida: Tallahassee, Florida State University, 280 p.

Fishman, M.J. and Friedman, L.C., eds., 1989, Methods for determination of inorganic substances in water and fluvial sediments: U.S. Geological Survey Techniques of Water-Resources Investigations, book 5, chap. A1, $545 \mathrm{p}$.

Florida Agricultural Statistical Service, 1991, Field crop summary 1990: Orlando, Florida Department of Agriculture and Consumer Services, $19 \mathrm{p}$.

_-1992a, Citrus summary 1990-1991: Orlando, Florida Department of Agriculture and Consumer Services, $45 \mathrm{p}$. -1992b, Livestock, dairy, and poultry summary 1991: Orlando, Florida Department of Agriculture and Consumer Services, $84 \mathrm{p}$. 1992c, Vegetable summary 1990-1991: Orlando, Florida Department of Agriculture and Consumer Services, $76 \mathrm{p}$.

Georgia Agricultural Statistics Service, 1993, Georgia agricultural facts; 1993 edition: Athens, Georgia Department of Agriculture, $98 \mathrm{p}$. 
Helsel, D.R. and Cohn, T.A., 1988, Estimation of descriptive statistics for multiply censored water quality data: Water Resources Research, vol. 24, p. 1997-2004.

Helsel, D.R., and Hirsch, R.M., 1992, Statistical methods in water resources: New York, Elsevier, 522 p.

Hodler, W.H., and Schretter, H.A., 1986, The atlas of Georgia: Athens, The Institute of Community and Area Development, The University of Georgia, $273 \mathrm{p}$.

Kay, Furman, and Hammond, Cecil, 1985, Land application of livestock and poultry manure: Athens, Cooperative Extension Service, The University of Georgia College of Agriculture, Leaflet 378, 4 p.

Madison, R.J., and Brunett, J.O., 1985, Overview of the occurrence of nitrate in ground water in the United States, in National Water Summary 1984--Hyrologic events, selected water-quality trends, and ground-water resources: U.S. Geological Survey Water-Supply Paper 2275, p. 93-105.

Marella, R.L. and Fanning, J.L., 1995, Water withdrawals and treated wastewater discharges in the GeorgiaFlorida Coastal Plain study unit, 1990: U.S. Geological Survey Water-Resources Investigations Report 95-4084.

McConnell, J.B. and Hacke, C.M., 1993, Hydrogeology, water quality, and water resource development potential of the Upper Floridan aquifer in the Valdosta area, south-central Georgia: U.S. Geological Survey Water-Resources Investigations Report 93-4044, 44 p.

McFadden, S.S., and Perreillo, P.D., 1983, Hydrogeology of the Clayton and Claiborne aquifers in southwestern Georgia, Geologic Survey Information Circular 55, 59 p.

Miller, J.A., 1986, Hydrogeologic framework of the Floridan aquifer system in Florida, and in parts of Georgia, Alabama, and South Carolina--Regional Aquifer System Analysis: U.S.Geological Survey Professional Paper 1403-B, 91 p. 1990, Ground water atlas of the United States, Segment 6, Alabama, Florida, Georgia, and South Carolina: U.S. Geological Survey Hydrologic Investigations Atlas 730-G, 28 p.

Mitchell, W.B., Guptill, S.C., Anderson, K.E., Fegeas, R.G., and Hallam, C.A., 1977, GIRAS--A geographic information retrieval and analysis system for handling land use and land cover data: U.S. Geological Survey Professional Paper 1059, $16 \mathrm{p}$.
Owenby, J.R., and Ezell, D.S., 1992a, Monthly station normals of temperature, precipitation, and heating and cooling degree days 1961-90, Florida: Asheville, N.C., U.S. Department of Commerce, National Oceanic and Atmospheric Administration, National Climate Data Center, $28 \mathrm{p}$.

Owenby, J.R., and Ezell, D.S., 1992b, Monthly station normals of temperature, precipitation, and heating and cooling degree days 1961-90, Georgia: Asheville, N.C., U.S. Department of Commerce, National Oceanic and Atmospheric Administration, National Climate Data Center, $32 \mathrm{p}$.

Ott, Lyman, 1988, An introduction to statistical methods and data analysis (3rd ed.): Boston, PWS-Kent Publishing Co., 835 p.

Owenby, J.R., and Ezell, D.S. 1992, Monthly station normals of temperature, precipitation, and heating and cooling degree days 1961-90: Asheville, N.C., U.S. Department of Commerce, National Oceanic and Atmospheric Administration, National Climate Data Center, Climatology of the United States no. 81, 26 p.

Perkins, H.F., and Shaffer, M.E., 1977, Soil associations and use potential of Georgia soils: Athens, Georgia Agricultural Experiment Station, University of Georgia, 1 sheet, scale 1:500,000).

Rosenau, J.C., Faulkner, G.L., Hendry, C.W.Jr., Hull, R.W., 1977, Springs of Florida: Florida Bureau of Geology Bulletin No. 31, 461 p.

SAS Institute, Inc., 1990, SAS/STAT User's Guide Version 6, Fourth Edition,: Cary N.C., SAS Institute, Inc., 2 volumes, p. 1198-1210.

Schiner, G.R., Laughlin, C.P., and Toth, D.J., 1988, Geohydrology of Indian River County, Florida: U.S. Geological Survey Water-Resources Investigations Report 88-4073, 110p.

Sprinkle, C.L., 1989, Geochemistry of the Floridan aquifer system in Florida and parts of Georgia, South Carolina, and Alabama: U.S. Geological Survey Professional Paper 1403-I, $105 \mathrm{p}$.

Tchobanoglous, George, 1991, Wastewater engineering, treatments, disposal, and reuse ( $3 \mathrm{~d}$ ed.): New York, Metcalf and Eddy, Inc., 2000 p.

Trommer, J.T., 1992, Effects of effluent spray irrigation and sludge disposal on ground water in a karst region, northwest Pinellas County, Florida: U.S. Geological Survey Water-Resources Investigations Report 91$4181,32 \mathrm{p}$.

U.S. Department of the Census, 1993, 1990 Census of housing, detailed housing characteristics, Florida: Washington, D.C., U.S. Department of Commerce, Bureau of the Census, 793 p. 
U.S. Environmental Protection Agency, 1990, Maximum contaminant levels (subpart B of part 141, National primary drinking water regulations) (revised July 1 , 1990): U.S. Code of Federal Regulations, Title 40, Parts 100-149, p. 559-563.

University of Florida, 1991a, Florida population: Census Summary 1990: Gainesville, University of Florida Bureau of Economy and Business Research, College of Business Administration, $55 \mathrm{p}$.
VanDyne, D.L., and Gilbertson, C.B., 1978, Estimating U.S. livestock and poultry manure and nutrient production, U.S. Department of Agriculture, Economics, Statistics, and Cooperatives Service-12, $150 \mathrm{p}$.

1991b, Florida statistical abstract 1991: Gainesville, University of Florida Bureau of Economy and Business Research, College of Business Administration, $736 \mathrm{p}$.

Wood, W.W., 1976, Guidelines for collection and field analysis of ground-water samples for selected unstable constituents: U.S. Geological Survey Techniques of Water-Resources Investigations, book 1, chap. D2, 24 p. 
